\title{
Impacts of New Particle Formation on Short-term Meteorology and Air Quality as Determined by the NPF-explicit WRF-Chem in the Midwestern United States
}

\author{
Can Dong $^{1}$, Hitoshi Matsui ${ }^{2}$, Scott Spak ${ }^{3}$, Alicia Kalafut-Pettibone ${ }^{4}$, Charles Stanier ${ }^{*}$ \\ ${ }^{I}$ Department of Chemical and Biochemical Engineering, University of Iowa, Iowa City, IA 52242, USA \\ ${ }^{2}$ Graduate School of Environmental Studies, Nagoya University, Nagoya 464-8601, Japan \\ ${ }^{3}$ School of Urban and Regional Planning, University of Iowa, Iowa City, IA 52242, USA \\ ${ }^{4}$ Schafer, A Belcan Company, Arlington, VA 22203, USA
}

\begin{abstract}
New particle formation (NPF) from nucleation and subsequent nuclei growth, which is frequently observed in the troposphere, is critical to aerosol-cloud interactions yet difficult to simulate. In this work, regional simulations with the fully coupled NPF-explicit WRF-Chem model link NPF to cloud properties and to changes in both meteorology and air quality in the U.S. Midwest during summer 2008. Simulations that include NPF have higher concentrations of condensation nuclei, as anticipated from the particle production associated with nucleation, leading to enhanced concentrations of cloud condensation nuclei $(\mathrm{CCN})$ at high supersaturations. However, the online-coupled model develops a number of unexpected features that can be traced to a feedback loop involving aqueous (in-cloud) oxidation of sulfur combined with boundary layer NPF. Simulations with NPF (relative to simulations without) exhibit reduced $\mathrm{PM}_{2.5}$ sulfate mass, cloud dimming (reductions in the cloud frequency, CCN concentration at a low supersaturation, cloud optical depth, and cloud droplet number concentration), and enhanced surface-reaching shortwave radiation. This effect of NPF on the $\mathrm{PM}_{2.5}$ mass is mostly absent for other constituents of $\mathrm{PM}_{2.5}$. The implications of this feedback loop, which is not considered in most climate and air quality modeling, are discussed.
\end{abstract}

Keywords: New particle formation; Meteorology; Air quality; Sulfate; WRF-Chem; Aerosol cloud interaction; Indirect climate effect.

\section{INTRODUCTION}

Atmospheric particles result from two source types: direct emissions or nucleation. Nucleation is a gas-to-particle conversion process which has been observed frequently throughout the world (Zhang et al., 2011; Kerminen et al., 2012; Yue et al., 2016), and is a dominant source of particle number in the global atmosphere (Spracklen et al., 2006; Merikanto et al., 2009). Clusters of particles around $1 \mathrm{~nm}$ in size are introduced by nucleation (Kulmala et al., 2000). Those clusters may grow via condensation to sufficiently large sizes $(\sim 100 \mathrm{~nm})$ to serve as cloud condensation nuclei (CCN) (Merikanto et al., 2009). Enhanced concentrations of CCN modify cloud amount, cloud optical properties, and precipitation efficiency of clouds and can thus impact climate (Twomey, 1977; Albrecht, 1989; Pincus and Baker, 1994; Paasonen et al., 2013; Farmer et al., 2015). Studies show

\footnotetext{
* Corresponding author.

Tel.: +01 319-335-1399; Fax: +01 319-335-1415

E-mail address: charles-stanier@uiowa.edu
}

that up to $50 \%$ of global $\mathrm{CCN}$ are attributable to nucleation (Merikanto et al., 2009; Yu and Luo, 2009; Wang and Penner, 2009). Detailed quantification of how new particle formation (NPF) affects climate remains uncertain, and the magnitude of aerosol indirect forcing is uncertain (Moore et al., 2013; Fan et al., 2016; Seinfeld et al., 2016). While the influence of NPF in altering particle number and CCN concentrations is widely acknowledged (Yu and Luo, 2009; Gordon et al., 2017), the potential feedbacks from NPF to other variables such as speciated aerosol mass, precipitation, and cloud liquid water content have not been investigated as widely and this work aims to close this research gap.

Two important characteristics of nucleation modeling studies are spatial scale (i.e., global or regional), and degree of coupling and feedbacks. Possible feedbacks that can be considered include those between NPF, clouds, radiation, aqueous aerosol chemistry, trace gases, and other meteorological variables.

Relative to global models, regional models are able to accommodate more computationally demanding process treatments and finer spatial resolutions; therefore, they are often used in conjunction with field campaigns and to assess the importance of various model processes and process 
feedbacks, often with a focus on the contribution of NPF to CCN. See for example Luo and Yu (2011) who used WRF-Chem + APM over the eastern U.S., Matsui et al. (2011, 2013) with the NPF-explicit WRF-Chem over East Asia, as well as other applications of NPF-explicit WRFChem variants (Cui et al., 2014; Lupascu et al., 2015). Similar to the aforementioned papers, our work includes assessment of the impact of NPF on CCN at regional scale using nucleation explicit WRF-Chem, but then extends beyond this metric to examine NPF's impact on a range of other climate- and health-relevant meteorological and air quality variables.

With respect to treatment of feedbacks, an important class of models are those with employing "offline" modeling systems; in other words, meteorology is prescribed and feedbacks between NPF aerosols, meteorology, clouds, and trace gases relevant to air quality are either limited or not considered at all.

More relevant to our aims of understanding the impact of feedbacks between NPF, clouds, and air quality are online coupled models. Several studies have investigated aerosol-meteorology interactions in the U.S., Europe and Asia by using the online WRF-Chem model (Zhang et al., 2010b; Yang et al., 2011; Shrivastava et al., 2013; Berg et al., 2015; Chen et al., 2015; Forkel et al., 2016; Liu et al., 2016), often with a focus on direct and indirect effects of anthropogenic aerosols; they include nucleation, but do not focus on nucleation. One reason for this is the lack of aerosol representation below $39 \mathrm{~nm}$ in MOSAIC (the Model for Simulating Aerosol Interactions and Chemistry), the most detailed aerosol module in the WRF-Chem public release (Zaveri et al., 2008). Furthermore, MOSAIC's binary nucleation parameterization underestimates PBL nucleation rates (Wexler et al., 1994; Lucas and Akimoto, 2006; Zhang et al., 2010a). Therefore, modifications to WRF-Chem are required for more detailed study of NPF impacts and to compare WRF-Chem to ultrafine and nuclei aerosol size distributions. The 20 size bin version of MOSAIC used in this paper (Matsui et al., 2011) ranges from the lower bin boundary of $1 \mathrm{~nm}$ to upper bin boundary of 10,000 nm and was coupled to WRF-Chem as the NPF-explicit WRF-Chem.

Nearly all nucleation studies report an increase in $\mathrm{CCN}$ due to NPF. Combining this with the first indirect effect (Twomey, 1977) and the second indirect effect (Albrecht, 1989), it is commonplace to associate NPF with cloud brightening, extended cloud lifetime, and negative radiative forcing. However, more complex relationships are possible at regional scale (Rosenfeld et al., 2008; Karydis et al., 2011; Kerminen et al., 2012; Sullivan et al., 2018).

As an example where a fully coupled regional model can give counterintuitive results, Sullivan et al. (2018) used the NPF-explicit WRF-Chem model to study the impact of NPF on cloud radiative properties over the Midwestern U.S. for May 2008. Contrary to prior expectations, they found NPF decreased cloud albedo, resulting in positive radiative forcing relative to simulations excluding NPF.

As in Sullivan et al. (2018), the coupled modeling system used in this work allows exploration of feedbacks among aerosols, trace gases relevant to air quality, and clouds over the continental U.S. in summer, providing an opportunity for replication of features reported by Sullivan et al. (2018), and adding tests for the roles of aqueous chemistry and biogenic secondary aerosol in the cloud dimming feedback process.

Furthermore, the NPF-explicit WRF-Chem model allows us to quantify the effects of nucleation on air quality, a topic that very few groups have reported on. The lack of documented results regarding interplay between NPF and air quality is largely due to extensive representation in the air quality literature by offline models at both regional and global scales (Merikanto et al., 2009; Yu and Luo, 2009; Jung et al., 2010; Yu and Hallar, 2014; Scott et al., 2015; Baranizadeh et al., 2016; Croft et al., 2016; Gordon et al., 2017). Some models couple aerosols to various model processes, but detailed assessment of processes in moderate to high $\mathrm{SO}_{2}$ regions are typically not reported; furthermore, differences in spatio-temporal resolutions, emissions, chemical process treatments, and aerosol size resolution make replication in higher resolution regional models useful. See, for example, Wang and Penner (2009), Kazil et al. (2010), Wang et al. (2011), Wang et al. (2013), Matsui and Mahowald (2017) and model intercomparisons such as Quaas et al. (2009), Myhre et al. (2013, 2017), Mann et al. (2014), and Tsigaridis et al. (2014).

In this work, we use the NPF-explicit WRF-Chem model to quantify the effects of nucleation on regional meteorology and air quality, including the modulating influence of aqueous chemistry. The primary analysis area is the Midwestern U.S., a 12-state region mainly covered by agricultural lands interspersed with forests, and home to $21 \%$ of the U.S. population. The work is relevant to understanding aerosol-cloud interactions and modeling feedbacks between NPF, air quality, and meteorology in similar mid-latitude temperate agricultural regions with moderate $\mathrm{PM}_{2.5}$ (e.g., 5-15 $\mu \mathrm{g} \mathrm{m}^{-3}$ ) and $\mathrm{SO}_{2}$ (e.g., 0.5-3 ppb). A number of measurement studies are available to complement model-based studies of aerosols and clouds in the region (Pryor et al., 2010; Sheridan et al., 2012; Asmi et al., 2013; Wagner et al., 2015; Toon et al., 2016; Bullard et al., 2017).

\section{METHOD}

\section{WRF-Chem Modeling System}

NPF-explicit WRF-Chem, as described in Matsui et al. (2011), was applied to this study without modification (settings were modified as explained below). Key features of NPF-explicit WRF-Chem include extension of the MOSAIC aerosol module (Zaveri et al., 2008) to allow 20 size bins from $1 \mathrm{~nm}$ to $10,000 \mathrm{~nm}$, implemented in WRF-Chem 3.1.1 (Grell et al., 2005; Fast et al., 2006). Activation nucleation and binary nucleation parameterizations are used in the PBL and FT, respectively. The formation rate of activated clusters at $1 \mathrm{~nm}$ in the PBL $(J)$ is calculated in the model by $\mathrm{J}=\mathrm{A} \times\left[\mathrm{H}_{2} \mathrm{SO}_{4}\right]$, where $A$ is the empirical rate coefficient $\left(\mathrm{s}^{-1}\right)$ and $\left[\mathrm{H}_{2} \mathrm{SO}_{4}\right]$ is gas-phase sulfuric acid concentration. The prefactor variable $A$ is set to $10^{-7} \mathrm{~s}^{-1}$ for this study, consistent with previously published values ranging from 
$10^{-8}$ to $2 \times 10^{-5} \mathrm{~s}^{-1}$ (Kuang et al., 2008; Cui et al., 2014; Sullivan et al., 2018).

In the NPF-explicit WRF-Chem employed in this study, aerosol particles influence grid-resolved cloud properties explicitly because size-resolved aerosols are an input to the Lin microphysics scheme and act as cloud nuclei (Lin et al., 1983). CCN are determined by the model at 6 supersaturations $(0.02 \%, 0.05 \%, 0.1 \%, 0.2 \%, 0.5 \%$, and $1.0 \%$ ) via Köhler theory, using particle number, size and composition. Particle activation is calculated by comparing ambient supersaturation with calculated critical supersaturation (Abdul-Razzak and Ghan, 2000). When cloud droplets evaporate, the model returns activated aerosol to the interstitial phase. The simulated cloud droplet number distribution is used by the Goddard scheme to calculate incoming solar radiation (Chou and Suarez, 1994). Cloud droplet number and cloud water mixing ratio are used for computing effective cloud-droplet size and COD. Sub-grid cumulus clouds in this study are simulated by the Grell-3D parameterization (Grell et al., 2005). Cumulus cloud properties are influenced through meteorological feedbacks by aerosols indirectly as aerosol activation is only simulated in the resolved clouds in this work. In more recent public releases of WRF-Chem (beginning with version 3.8), aerosols can be online coupled with the convective parameterization (Berg et al., 2015).

Model and emissions configurations are listed in Table 1. No biomass burning emissions are included in the simulations. A $36 \times 36 \mathrm{~km}$ resolution domain over the continental U.S. is used with 34 vertical layers on top at about $16 \mathrm{~km}$ above ground level. An area corresponding to the Midwestern U.S. $\left(79.5^{\circ} \mathrm{W}-103.5^{\circ} \mathrm{W}, 36.5^{\circ} \mathrm{N}-48.5^{\circ} \mathrm{N}\right)$ comprises a data analysis sub-region. The simulation period covers 20 June to 22 July 2008, with 3 days for model spin-up.

\section{Numerical Experiments}

Table 2 lists the primary numerical experiments performed in this study. In case N11A1, both PBL and FT nucleation are included, and aqueous chemistry is considered as well, and N11A1 is the base simulation. In case N01A1, only FT nucleation is included, while in the N00A1 case, both PBL and FT nucleation are turned off. For these three cases, the simulations are run continuously for the entire modeling period without reinitialization. N11A0 and N01A0 cases are one-week simulations (excluding 3-day spin-up) evaluating sensitivity to aqueous chemistry from 20 June to 30 June. Sensitivity tests are performed in two additional scenarios to explore the impact of model resolution and maximum supersaturation $\left(\mathrm{S}_{\mathrm{max}}\right)$.

Table 1. Model configuration.

\begin{tabular}{|c|c|c|}
\hline Atmospheric processes & Model option & Reference \\
\hline \multicolumn{3}{|l|}{ Meteorology } \\
\hline Longwave radiation & RRTM & Mlawer et al. (1997) \\
\hline Shortwave radiation & Goddard & Chou et al. (1994) \\
\hline Land surface model & Noah LSM & Chen and Dudia (2001) \\
\hline PBL scheme & YSU & Hong et al. (2006) \\
\hline Cumulus & Grell 3D & Grell and Devenyi (2002) \\
\hline Cloud microphysics & Lin & Lin et al. (1983) \\
\hline Initial and boundary conditions & $\begin{array}{l}\text { NCEP FNL (Final) Operational } \\
\text { Global Analysis data }\end{array}$ & https://rda.ucar.edu/datasets/ds083.2/ \\
\hline \multicolumn{3}{|l|}{ Chemistry } \\
\hline Gas-phase chemistry & CBMZ & Zaveri and Peters (1999) \\
\hline Photolysis & Fast- J & Wild et al. (2000) \\
\hline Aerosol condensation & MOSAIC-4 & Zaveri et al. (2008) \\
\hline Aerosol coagulation & COAGSOLV & Jacobson et al. (1994) \\
\hline Aqueous-phase chemistry & Bulk approach & Fahey and Pandis (2001) \\
\hline Anthropogenic emissions & 2005 NEI & \\
\hline Biogenic emissions & MEGAN & Guenther et al. (2006) \\
\hline Sea salt emissions & online & Monahan et al. (1986) and Gong (2002) \\
\hline Dust emissions & online & Shaw et al. (2008) \\
\hline Initial and boundary conditions & MOZART & Emmons et al. (2010) \\
\hline
\end{tabular}

Table 2. Model experiments.

\begin{tabular}{llll}
\hline Case name & PBL Nucleation & FT Nucleation & Aqueous Chemistry \\
\hline N11A1 & AN & BHN & On \\
N01A1 & No nucleation & BHN & On \\
N00A1 & No nucleation & No nucleation & On \\
N11A0 & AN & BHN & Off \\
N01A0 & No nucleation & BHN & Off \\
\hline
\end{tabular}

${ }^{\mathrm{a}} \mathrm{AN}$ : activation nucleation. BHN: binary homogeneous nucleation. 
Initial and boundary conditions are the same for all simulations, and nudging is not used.

\section{Evaluation Data Sources}

Surface meteorology, including $2 \mathrm{~m}$ temperature (T2), $2 \mathrm{~m}$ water vapor mixing ratio (Q2), $10 \mathrm{~m}$ wind speed (WS10) and wind direction (WD10) for a total of 97 stations in the Midwest are used (Table S1). Soundings of temperature $(\mathrm{T})$ and relative humidity $(\mathrm{RH})$ at Davenport, Iowa, are used for evaluating vertical profiles of meteorology. Surface measurements of bulk and speciated aerosol concentrations $\left(\mathrm{PM}_{2.5}, \mathrm{SO}_{4}{ }^{2-}\right.$ and black carbon), $\mathrm{SO}_{2}$, and MODIS AOD are compared with model output (data sources in Table S1). AERONET AOD from Bondville, IL, and sizeresolved particle number concentrations from West Branch, Iowa (Pettibone, 2009), are also used in model evaluation.

\section{RESULTS AND DISCUSSION}

\section{Model Evaluation}

Measured and predicted values (meteorology and chemistry) from the N11A1 case are summarized in Table 3. Variables listed in Table 3 are also evaluated for N01A1 and N00A1. Results for those cases, and statistical metric definitions, can be found in supplemental information. Fractional bias (FB), fractional error (FE), mean bias (MB), mean error (ME), root mean square error (RMSE) and correlation coefficient $(\mathrm{R})$ are reported, with percentage bias and error relative to measurement means. The performance statistics from different cases for both meteorology and species are generally similar. Noticeable sensitivity occurs for $\mathrm{SO}_{4}{ }^{2-}$ and $\mathrm{SO}_{2}$. For $\mathrm{SO}_{4}{ }^{2-}, \mathrm{N} 11 \mathrm{~A} 1$ shows the best performance for all statistical metrics; for $\mathrm{SO}_{2}$, the performance of N11A1 is either better or between that of N01A1 and N00A1.

\section{Meteorology Evaluation}

Predicted daily T2, WS10, WD10 and Q2 generally agree with observation. T2 is simulated with a correlation coefficient of 0.91 and a bias of $0.80 \mathrm{~K}$. WS10 is persistently overestimated (MB: $0.59 \mathrm{~m} \mathrm{~s}^{-1}$ [13.8\%]; FE: 0.53; FB: 0.59). Similar positive biases are common in WRF-Chem studies, with possible attribution to horizontal resolution and unresolved topographical features (Zhang et al., 2010b; Tuccella et al., 2012). WD10 is simulated well $\left(\mathrm{r}=0.96 ; \mathrm{MB}: 4.36^{\circ}\right) . \mathrm{Q} 2$ is also reproduced suitably (MB: $\left.0.15 \mathrm{~g} \mathrm{~kg}^{-1}[1.28 \%] ; \mathrm{r}=0.93\right)$.

The model also reproduces vertical profiles of temperature and water vapor mixing ratio (Fig. S2). Water vapor mixing ratio near the surface was overestimated (underestimated) during nighttime (daytime). Variations are relatively small in the model which could be explained by the model's limited vertical resolution.

\section{Air Pollutant Evaluation}

As the purpose of the study is sensitivity to NPF, bias and error in simulating observed concentrations of air pollutants are most relevant to their influence on the sensitivity results.

Table 3 shows that the monthly average $\mathrm{SO}_{4}{ }^{2-}$ concentration is overpredicted by $0.44 \mu \mathrm{g} \mathrm{m}^{-3}$ (20.1\%), while the black carbon $(\mathrm{BC})$ concentration is underpredicted by $0.07 \mu \mathrm{g} \mathrm{m}^{-3}(25.9 \%)$. A possible source of positive bias of $\mathrm{SO}_{4}{ }^{2-}$ could be $\mathrm{SO}_{2}$ overestimation. As shown in Table 3 , $\mathrm{SO}_{2}$ is predicted with a positive bias of $0.92 \mathrm{ppb}(29.8 \%)$. Underestimation of $\mathrm{BC}$ may be the result of errors in anthropogenic emissions, the absence of wildfire emissions, and biases in the meteorological fields (for example, the overprediction of temperature indicates PBL height might be over-predicted as well). $\mathrm{PM}_{2.5}$ is underpredicted, which is expected, as this simulation did not include SOA formation except in sensitivity tests. Performance for $\mathrm{PM}_{2.5}, \mathrm{SO}_{4}{ }^{2-}$, and $\mathrm{BC}$ exceed the $75^{\text {th }}$ percentile for $\mathrm{r}^{2}$, and are consistent with the middle $50 \%$ on bias and error metrics compared to prior U.S. photochemical grid modeling studies compiled by Simon et al. (2012). Using FB and FE results criteria from Morris et al. (2005), all chemical species fall into the "good" or "average" classifications. Comparing to more stringent and recent performance goals (Emery et al., 2017), black carbon meets suggested criteria for normalized mean bias (NMB), normalized mean error (NME), and r. $\mathrm{PM}_{2.5}$ meets two of three criteria (NMB exceeds $30 \%$ ). $\mathrm{SO}_{4}{ }^{2-}$ meets the correlation criteria (it exceeds $r$ of 0.7 ) while slightly exceeding the NMB and NME recommended criteria.

Model-measurement comparison of AOD at $550 \mathrm{~nm}$ (Fig. S3) shows similar accuracy to previously reported results (Mashayekhi et al., 2014), with underprediction in the eastern U.S., as expected in summer modeled with SOA absent. Mean observed and modeled AOD measurement at the Midwest location of Bondville, IL, are 0.17 and 0.12, respectively (also shown in Fig. S3).

Table 3. Observed and modeled meteorological and chemical species.

\begin{tabular}{lllllllll}
\hline & Mean obs & Mean model & FB & FE & MB & ME & RMSE & r \\
\hline $\mathrm{T} 2(\mathrm{~K})$ & 295.50 & 296.30 & & & 0.80 & 0.93 & 1.26 & 0.91 \\
$\mathrm{WS} 10\left(\mathrm{~m} \mathrm{~s}^{-1}\right)$ & 3.85 & 4.38 & & & 0.53 & 0.55 & 0.67 & 0.89 \\
$\mathrm{WD} 10\left({ }^{\circ}\right)$ & 210.86 & 215.23 & & & 4.36 & 14.54 & 18.86 & 0.96 \\
$\mathrm{Q} 2\left(\mathrm{~g} \mathrm{~kg}^{-1}\right)$ & 11.76 & 11.90 & & & 0.15 & 0.48 & 0.59 & 0.94 \\
$\mathrm{SO}_{4}^{2-}\left(\mu \mathrm{g} \mathrm{m}^{-3}\right)$ & 2.21 & 2.65 & 0.20 & 0.43 & 0.45 & 0.99 & 1.72 & 0.81 \\
$\mathrm{BC}\left(\mu \mathrm{g} \mathrm{m}^{-3}\right)$ & 0.27 & 0.20 & -0.22 & 0.50 & -0.07 & 0.12 & 0.21 & 0.46 \\
$\mathrm{PM}_{2.5}\left(\mu \mathrm{g} \mathrm{m}^{-3}\right)$ & 9.15 & 6.02 & -0.45 & 0.56 & -3.13 & 4.08 & 6.17 & 0.56 \\
$\mathrm{SO}(\mathrm{ppb})$ & 3.09 & 4.01 & 0.27 & 0.73 & 0.92 & 2.57 & 3.83 & 0.30 \\
$\mathrm{CO}(\mathrm{ppb})$ & 272.16 & 219.60 & -0.17 & 0.42 & -52.49 & 106.04 & 137.49 & 0.33 \\
$\mathrm{O}_{3}(\mathrm{ppb})$ & 35.10 & 44.85 & 0.24 & 0.28 & 9.76 & 11.23 & 14.18 & 0.44 \\
\hline
\end{tabular}




\section{Particle Number Concentrations}

$\mathrm{CN}_{10-63}(10$ to $63 \mathrm{~nm})$ are evaluated against 310 hours of measurements from West Branch, Iowa; they are reproduced within a factor of two and with a correlation coefficient of 0.42 (Fig. 1). Maps of surface $\mathrm{CN}$ can be found in supplemental information. Period averaged $\mathrm{CN}_{10-63}$ from the model and observation are $9228 \mathrm{~cm}^{-3}$ and $4873 \mathrm{~cm}^{-3}$, respectively. The model performance is similar to that of Matsui et al. (2013). They found $\mathrm{CN}_{10}$ at two sites in the outflow regions of East Asia were overpredicted by factors of 1.6 and 1.7 , respectively. Performance is improved over prior reported evaluation of aerosol number concentration in the region, where Spak and Holloway (2009) compared CMAQ simulations (36 km resolution) with hourly observations at Bondville. Yu et al. (2015) using GEOSChem-APM $\left(\mathrm{CN}_{10-100}\right)$ and Sullivan et al. (2018) using NPF explicit WRF-Chem $\left(\mathrm{CN}_{6-25}\right)$ both report hourly correlation coefficients of $\sim 0.2-0.5$, depending on parameterization and season. Mann et al. (2014) examined the global variation in particle size distribution using 12 global aerosol microphysics models. They found that the best estimate of the annual mean particle concentrations (for $\mathrm{CN}_{3}, \mathrm{CN}_{10}$ or $\mathrm{CN}_{14}$ ) were within a factor 2 of the observations at all 13 sites, including Bondville, IL (Midwestern U.S.).

The N01A1 scenario predicted a lower mean $\mathrm{CN}_{10-63}$ $\left(4735 \mathrm{~cm}^{-3}\right)$ that was closer to the observed mean but with an inferior correlation coefficient ( 0.33 vs. 0.42$)$. Overprediction in the N11A1 case is most pronounced in the smallest sizes, caused in part by insufficient growth of nuclei due to our assumption of only inorganic secondary growth. Although this causes bias at the smallest sizes and a shift between observed (high number mean diameter) and simulated (lower number mean diameter) size distributions, our results focus mainly on the potential for feedbacks between nuclei, clouds, precipitation, and aerosol mass in the coupled nucleation explicit WRF-Chem system. This potential is assessed by model-model comparisons, and robustness of conclusions is checked by sensitivity runs including SOA. However, due to the overprediction of nuclei and ultrafine particles in this study, and the lack of SOA in the base case runs, we likely overestimate some of the microphysicalchemical feedbacks. The magnitude of the effects reported here should be considered as an upper limit that should be refined by future work.

\section{Influence of NPF on Key Modeled Parameters $C N$ and $C C N$}

Table 4 lists the monthly mean $\mathrm{CN}$ and $\mathrm{CCN}$ concentrations from different simulations. As expected, simulations that include nucleation in the FT (N01A1) or the FT and PBL (N11A1) have higher number concentrations of $\mathrm{CN}_{20}$ relative to N00A1 $\left(\mathrm{CN}_{x}\right.$ is used throughout for the number concentration larger than $x \mathrm{~nm}$ ). $\mathrm{CN}_{50}$ and $\mathrm{CN}_{100}$ behave similarly. FT nucleation has a strong impact on surface $\mathrm{CN}$ concentrations, consistent with other studies (Merikanto et al., 2009; Spracklen et al., 2010); however, study of the FT nucleation impacts on boundary layer air quality, meteorology, and cloud properties is beyond the scope of the current work.

Results for $\mathrm{CCN}$ at high supersaturations are similar to those for $\mathrm{CN}$. At $0.5 \%$ and $1 \%$ supersaturation, higher particle number concentrations in simulations with nucleation lead to higher CCN concentrations (Table 4). However, CCN at low supersaturation $(0.1 \%)$ are highest without nucleation

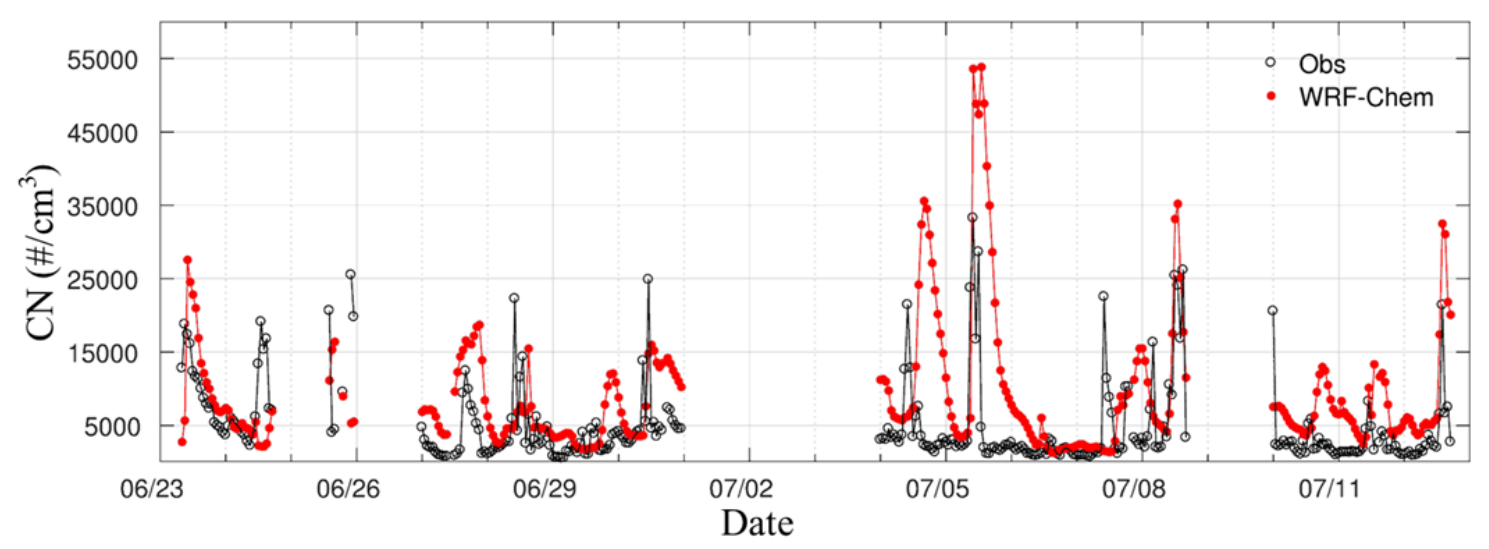

Fig. 1. Observed (black) and modeled (red, N11A1 simulation) CN (10-63 nm) at the West Branch, Iowa (WBI), site.

Table 4. Monthly-mean $\mathrm{CN}$ and $\mathrm{CCN}$ concentrations. Averages are calculated for the surface layer within the Midwest subdomain shown in Fig. S1, \pm represent the spatial standard deviation of the monthly mean.

\begin{tabular}{lllllll}
\hline Cases & CN20 & CN50 & CN100 & CCN $_{0.1}{ }^{\mathrm{a}}$ & $\mathrm{CCN}_{0.5}{ }^{\mathrm{b}}$ & $\mathrm{CCN}_{1.0}{ }^{\mathrm{c}}$ \\
\hline N11A1 & $7198 \pm 3011$ & $3668 \pm 1584$ & $1430 \pm 750$ & $130 \pm 80$ & $1740 \pm 759$ & $3190 \pm 1248$ \\
N01A1 & $5816 \pm 2389$ & $3448 \pm 1474$ & $1415 \pm 751$ & $145 \pm 85$ & $1651 \pm 708$ & $2866 \pm 1070$ \\
N00A1 & $1418 \pm 724$ & $1159 \pm 592$ & $696 \pm 367$ & $164 \pm 82$ & $552 \pm 252$ & $675 \pm 290$ \\
\hline
\end{tabular}

${ }^{a}$ Number concentration of CCN at $0.1 \%$ supersaturation, in $\# \mathrm{~cm}^{-3}$.

${ }^{\mathrm{b}}$ Number concentration of CCN at $0.5 \%$ supersaturation, in $\# \mathrm{~cm}^{-3}$.

${ }^{\mathrm{c}}$ Number concentration of $\mathrm{CCN}$ at $1.0 \%$ supersaturation, in $\# \mathrm{~cm}^{-3}$. 
(N00A1) and decrease in simulations with nucleation. Nucleation generates more small particles inhibiting the growth of preexisting particles, as well as decreasing hygroscopicity through inhibited accumulation mode sulfate condensation. Similar decreases in $\mathrm{CCN}$ concentrations at low supersaturations were reported by Matsui et al. (2011), but with smaller sensitivity to NPF. Cloud microphysics and aqueous chemistry configurations matched between the two studies, while grid nudging and aerosol-radiation feedback settings differed.

\section{NPF Effect on Boundary Layer Clouds}

Similar to the decreases in $\mathrm{CCN}$ at low supersaturations when NPF is active in the boundary layer (assessed by calculating the difference N11A1 minus N01A1), boundary layer NPF suppresses cloud droplet number concentration (CDNC), cloud liquid water path (LWP), and COD. CDNC concentrations are highest over the eastern part of the Midwest in the N01A1 simulation. LWP and COD are also high at the same location (Fig. S5). Noticeable CDNC reductions, resulting from turning $\mathrm{PBL}$ nucleation on, can be seen in these high CDNC regions. Changes in LWP and COD are similar in direction to the CDNC changes. PBL nucleation also leads to lower cloud occurrence frequency. LWP and COD changes linked to CDNC changes have been found in previous studies as well, but in those instances, CDNC changes were not linked to NPF (Yang et al., 2011; Makar et al., 2015).

Sullivan et al. (2018) used NPF explicit WRF-Chem modeling system (based on ver. 3.6.1), and a nearly matching time period, with higher horizontal resolution $(4 \mathrm{~km})$, and with resolved cumulus clouds. Our results are similar in the direction of the effect, and are based on version 3.1.1 rather than 3.6.1. The differences between the works are complementary. The difference in model version suggest the effect is not significantly mediated by recent enhancements or structural choices. Our simulations indicate that the effect is resolved at regional scales $(36 \mathrm{~km}$ and $9 \mathrm{~km}$ ) and not dependent on local convective processes resolved at the higher resolution of Sullivan et al. (2018) $(4 \mathrm{~km})$, and that sensitivity tests addressing resolution are robust. Biogenic contribution was neglected in Sullivan et al. (2018) and considered in this work, as were the individual process feedbacks creating the dimming.

\section{NPF Effect on Air Pollutant Concentrations}

Fig. 2 shows the absolute impacts of PBL nucleation (N11A1-N01A1) in monthly averaged surface $\mathrm{PM}_{2.5}, \mathrm{CO}$, $\mathrm{O}_{3}$ and $\mathrm{SO}_{2}$. A decrease in $\mathrm{PM}_{2.5}$ mass concentration over the Midwest is shown in Fig. 2(a). Midwest mean $\mathrm{PM}_{2.5}$ concentrations from the N11A1 and N01A1 simulations are 6.04 and $6.56 \mu \mathrm{g} \mathrm{m}^{-3}$, respectively. By including boundary layer nucleation, $\mathrm{PM}_{2.5}$ is reduced by $8.0 \%$ on average. This decrease in $\mathrm{PM}_{2.5}$ is due to reduction in secondary inorganic species, especially $\mathrm{SO}_{4}{ }^{2-}$. Compared to the N01A1 simulation, Midwest surface $\mathrm{SO}_{4}{ }^{2-}$ in the N11A1 simulation decreases by $0.37 \mu \mathrm{g} \mathrm{m}^{-3}$ on average, accounting for $71.2 \%$ of the $\mathrm{PM}_{2.5}$ reduction. Concentrations of other species are much less sensitive to NPF. Ground level CO and $\mathrm{O}_{3}$ also decrease slightly in most areas in the N11A1 simulation, likely due to increases in the average PBL height in the N11A1 simulation, as shown in Fig. 4(d). Changes in $\mathrm{SO}_{2}$ concentrations are significant in magnitude (up to $20 \%$ ) but spatially inhomogeneous. We are aware of no other studies reporting a reduction of $\mathrm{PM}_{2.5}$ sulfate due to the inclusion of NPF in a model, and we discuss the causes and implications below.

The spatial pattern to the $\mathrm{PM}_{2.5}$ decrease (Fig. 2(a)) is similar to that of the decrease in $\mathrm{CCN}$ concentration at low supersaturations, as is expected since larger particles that can activate at low supersaturations are a substantial portion of the mass distribution (Fig. 8).

In contrast to surface $\mathrm{PM}_{2.5}$, surface $\mathrm{SO}_{4}{ }^{2-}$, and $\mathrm{CCN}$ concentrations at low supersaturations, AOD is left mainly unchanged from the inclusion of NPF in the simulation (Fig. 3(c)), and the changes are spatially similar to changes in sulfate column loading (Figs. 3(d)-3(f)). Surface sulfate changes are slightly more pronounced than column sulfate changes because of changes in the sulfate vertical profile and higher PBL height in simulations with NPF. The AOD increase in the western part of the Midwest (Fig. 3(i)) is likely due to aerosol water.

\section{NPF Effect on Meteorology}

Sensitivity of meteorology to NPF is assessed by comparing N11A1 and N01A1, as shown in Fig. 4. Two types of patterns are observed. In the eastern portions of the Midwest, decreases in average cloud cover occurred with corresponding decreases in water vapor mixing ratio $(\mathrm{Q} 2)$, and increases in shortwave radiation (SWDOWN), surface temperature (T2), and PBL height. In western portions of the Midwest, the opposite set of changes to meteorology occur. These patterns are in Fig. 4 for SWDOWN (Panel a), Q2 (Panel b), T2 (Panel c) and PBL height (Panel d), and can be compared to changes in cloud optical depth (Fig. S5). Averaging across the entire domain, and considering grid cells with clouds in both N11A1 and N01A1, turning NPF on increases $\mathrm{CN}_{25}$ by $497 \mathrm{~cm}^{-3}$ (9.4\% increase relative to N01A1 for these grid cells), but decreases cloud droplet number concentration (CDNC) from $66.2 \mathrm{~cm}^{-3}$ (average for N01A1 in these paired grid cells) to $58.4 \mathrm{~cm}^{-3}$, a $11.8 \%$ decrease in CDNC. Since the Twomey effect establishes that the sensitivities of CDNC to increases in particle number are positive when all other factors (water availability, updraft velocity, hygroscopicity, etc.) are constant, this result runs counter to a priori expectations. See, for example, Moore et al. (2013), where for polluted conditions ( $\mathrm{CN}=$ $\left.\sim 5,000 \mathrm{~cm}^{-3}\right), \partial \ln (\mathrm{CDNC}) / \partial \ln (\mathrm{CN})$ is 0.21 (the corresponding median slope of all $\mathrm{BL}$ parcels at $\mathrm{CN}=\sim 5,000 \mathrm{~cm}^{-3}$ in our work is -0.35 ). Reasons for the negative sensitivity in the current work are discussed below.

The magnitude of changes reaches up to $+66.4 \mathrm{~W} \mathrm{~m}^{-2}$ for monthly averaged shortwave radiation. T2 is influenced by a variety of factors, such as shortwave radiation, soil moisture and soil temperature. In the southwest of the area analyzed, T2 decreases by more than $1 \mathrm{~K}$, and Q2 increases by more than $1.6 \mathrm{~g} \mathrm{~kg}^{-1}$, consistent with precipitation enhancement (Fig. S7). PBL heights increase by up to $90.5 \mathrm{~m}$ 

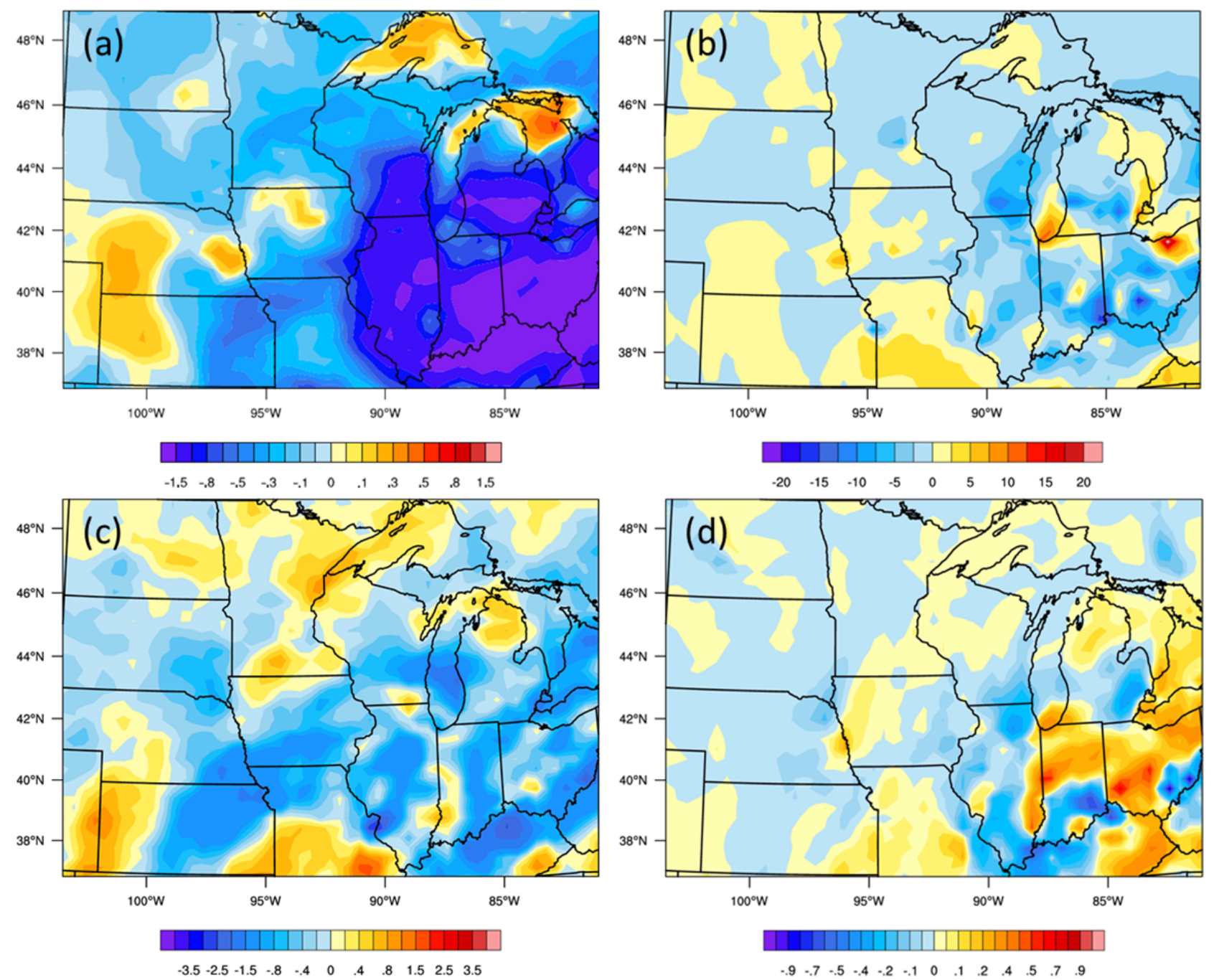

Fig. 2. Absolute changes (N11A1-N01A1) in surface concentrations of (a) $\mathrm{PM}_{2.5}\left(\mu \mathrm{g} \mathrm{m}^{-3}\right)$, (b) $\mathrm{CO}$ (ppb), (c) $\mathrm{O}_{3}$ (ppb), and (d) $\mathrm{SO}_{2}(\mathrm{ppb})$.

as a result of surface warming in most areas of the Midwest. Reduced PBL heights are simulated in locations where the N11A1 simulation has lower shortwave radiation and lower surface temperature relative to N01A1.

\section{Discussion of $\mathrm{PM}_{2.5}$ Decrease}

The $\mathrm{PM}_{2.5}$ reduction simulated with PBL nucleation on (mainly due to $\mathrm{PM}_{2.5}$ sulfate reduction) is potentially important for a number of applications, and the modeling system was exploited to establish its cause. In general, a sulfate mass concentration decrease must be from either weakening of a $\mathrm{SO}_{4}{ }^{2-}$ source, or strengthening of a sink. $\mathrm{SO}_{4}{ }^{2-}$ sources in WRF-Chem are primary emissions, and gas phase and in-cloud oxidation of $\mathrm{SO}_{2} . \mathrm{SO}_{4}{ }^{2-}$ is removed from the model atmosphere by wet and dry deposition. A number of model-model comparisons and sensitivity runs were conducted to investigate how $\mathrm{SO}_{4}{ }^{2-}$ sources and sinks were changing. Key results from these tests are discussed below; a full list of tests and associated inferences is also reported (Table S4).

Column integrated $\mathrm{SO}_{4}{ }^{2-}$ and $\mathrm{SO}_{2}$ are compared in
Fig. 5 to see if decreased conversion from $\mathrm{SO}_{2}$ to $\mathrm{SO}_{4}{ }^{2-}$ explains the changes in $\mathrm{SO}_{4}{ }^{2-}$ concentrations. Column integration is across model layers $1-10(\sim 2 \mathrm{~km})$. In the $\mathrm{SO}_{4}{ }^{2-}$ reduction regions, column $\mathrm{SO}_{2}$ increases. For the most polluted Midwest region as shown in the red square in Fig. 7(a), the spatial average of column $\mathrm{SO}_{2}$ and $\mathrm{SO}_{4}{ }^{2-}$ changes are +101.8 and $-94.5 \mathrm{mmol} \mathrm{m}^{-2}$, respectively. The increase of $\mathrm{SO}_{2}$ and decrease of $\mathrm{SO}_{4}{ }^{2-}$ are approximately equal, and we attribute the bulk of the $\mathrm{SO}_{4}{ }^{2-}$ mass decrease (in $\mathrm{N} 11 \mathrm{~A} 1$ ) to less robust oxidation of $\mathrm{SO}_{2}$. In other words, the source of $\mathrm{SO}_{4}{ }^{2-}$ decreases, rather than the sink increasing.

The influence of wet deposition on $\mathrm{SO}_{4}{ }^{2-}$ is investigated by comparing the timing of precipitation with the $\mathrm{SO}_{4}{ }^{2-}$ time series in N11A1 and N01A1. For wet deposition to be an important factor in the influence of NPF on $\mathrm{SO}_{4}{ }^{2-}$, we expect model-model differences to be maximized, or to increase, during periods of significant precipitation. Significant precipitation events occurred on 24 June and 29 June (Fig. S6). However, $\mathrm{SO}_{4}{ }^{2-}$ differences between model runs do not match temporal trends in precipitation. 

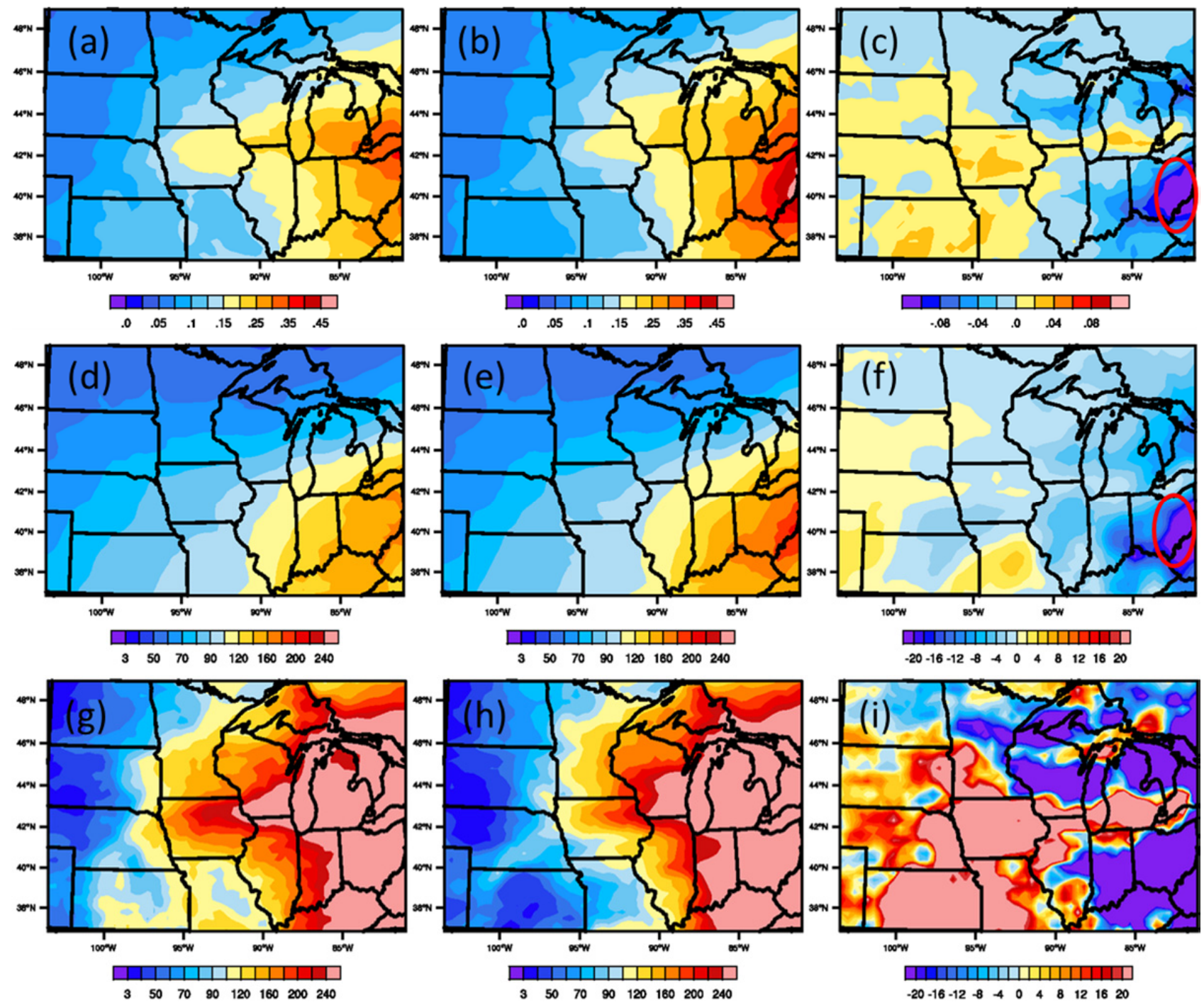

Fig. 3. Monthly average of column (a-c) AOD, $(\mathrm{d}-\mathrm{f}) \mathrm{SO}_{4}{ }^{2-}\left(\mu \mathrm{g} \mathrm{m}{ }^{-2}\right)$ and $(\mathrm{g}-\mathrm{i})$ aerosol water $\left(\mu \mathrm{g} \mathrm{m}^{-2}\right)$. From left to right: N11A1, N01A1, N11A1-N01A1.

Dry deposition is ruled out as a main cause of the modeled $\mathrm{SO}_{4}{ }^{2-}$ decrease by comparison of $\Delta \mathrm{SO}_{4}{ }^{2-}$ at the surface to $\Delta \mathrm{SO}_{4}{ }^{2-}$ at model layer 7 ( $\sim 850 \mathrm{~m}$ above ground). Since dry deposition acts at the surface, its effect would be most pronounced at the lowest model layer. However, $\Delta \mathrm{SO}_{4}{ }^{2-}$ (Fig. 6(a)) is similar at both elevations.

To elucidate the relative impacts of gas phase and aqueous chemistry in the weakening of sulfur oxidation, model runs were performed with aqueous chemistry turned off, but with PBL nucleation active (N11A0) or inactive (N01A0). The results of the sensitivity tests (for Midwest averaged surface $\mathrm{PM}_{2.5}$ and $\mathrm{SO}_{4}{ }^{2-}$ ) are shown in Table 5 . These additional runs both show a decrease in $\mathrm{SO}_{4}{ }^{2-}$ from $\mathrm{NPF}$, so the direction of the NPF effect is the same as in the longer base and N01A1 runs. But the magnitude of the effect is much larger when both NPF and aqueous chemistry are active. Specifically, a $1.1 \%$ sulfate decrease occurs without aqueous chemistry, compared to a $13.0 \%$ sulfate decrease with aqueous chemistry. We therefore conclude that NPF and aqueous chemistry act together as the primary cause of the nucleation effect on $\mathrm{PM}_{2.5}$ mass.

Fig. 7 shows mean surface $\Delta \mathrm{SO}_{4}{ }^{2-}$. The result is consistent with the spatially averaged values from Table 5 discussed above. Without aqueous chemistry, the influence of NPF on $\mathrm{SO}_{4}{ }^{2-}$ concentration is small (Fig. 7(b)) and centered in the eastern portion of the Midwest and eastern U.S. In other words, the combined effects of aqueous chemistry and NPF are needed to explain the bulk of the reduced $\mathrm{SO}_{4}{ }^{2-}$ concentrations and reduced $\mathrm{SO}_{2} \rightarrow \mathrm{SO}_{4}{ }^{2-}$ conversion.

We also attribute a portion of the $\mathrm{SO}_{4}{ }^{2-}$ reduction to decrease in the gas phase $\mathrm{OH}$ radical. The $\mathrm{OH}$ reduction and its potential causes are explored in supplemental material (Fig. S8). In summary, biogenic emissions $(\sim 10 \%$ increase due to higher temperatures and SW radiation) are enhanced and water vapor decreases in the NPF on simulations. Increased VOCs shorten the $\mathrm{OH}$ lifetime (Archer-Nicholls et al., 2014; Yahya et al., 2014). Dilution of $\mathrm{SO}_{4}{ }^{2-}$ through PBL height increase was investigated and found to be a minor contribution, based on the insensitivity of primary aerosols to PBL nucleation. 
Interactions of Aqueous Chemistry, Cloud Droplets, and Aerosol Size Distributions

With PBL nucleation on, cloud water in the lower
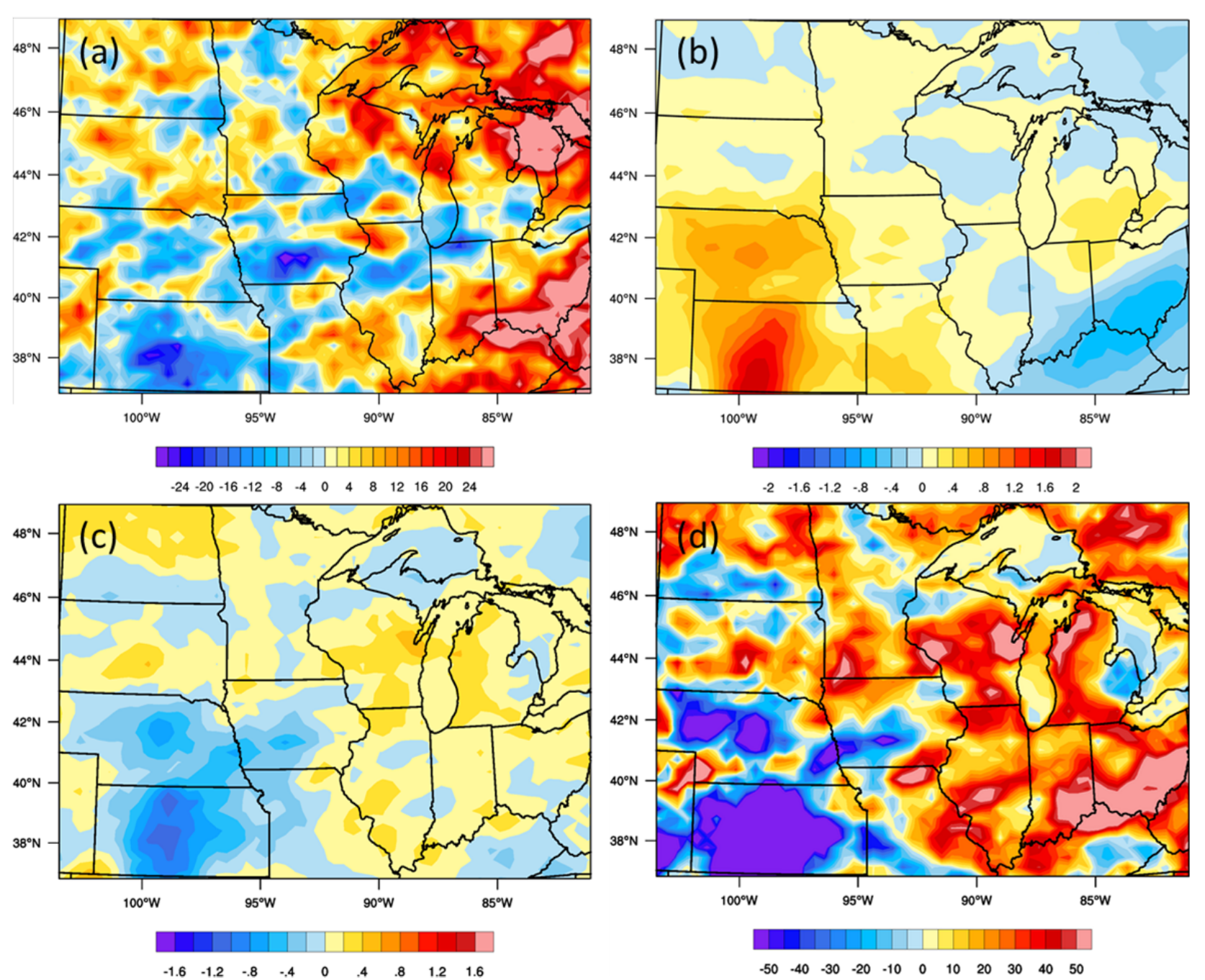

Fig. 4. Absolute changes (N11A1-N01A1) in (a) downwelling solar radiation $\left(\mathrm{W} \mathrm{m}^{-2}\right)$, (b) surface water vapor mixing ratio Q2 $\left(\mathrm{g} \mathrm{kg}^{-1}\right)$, (c) $2 \mathrm{~m}$ temperature $(\mathrm{K})$, and (d) PBL height (m).
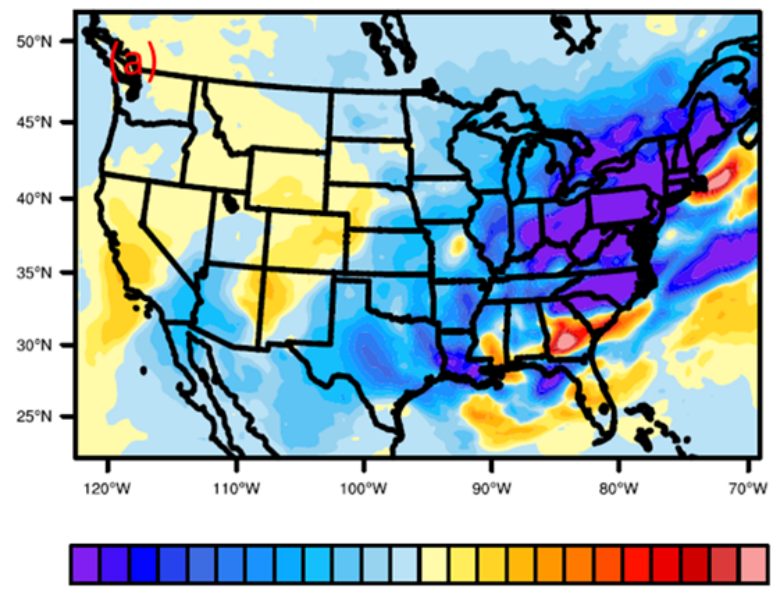

$\begin{array}{lllllllllll}-90 & -70 & -50 & -30 & -10 & 0 & 10 & 30 & 50 & 70 & 90\end{array}$ troposphere $(0-2 \mathrm{~km})$ decreases by over $30 \%$ in most parts of the region with high $\mathrm{SO}_{4}{ }^{2-}$ (Fig. S9), reducing the extent of aqueous sulfate production. Cloud water content increases

$\begin{array}{rrrrrrrrrrr}-50 & -40 & -30 & -20 & -10 & 0 & 10 & 20 & 30 & 40 & 50\end{array}$
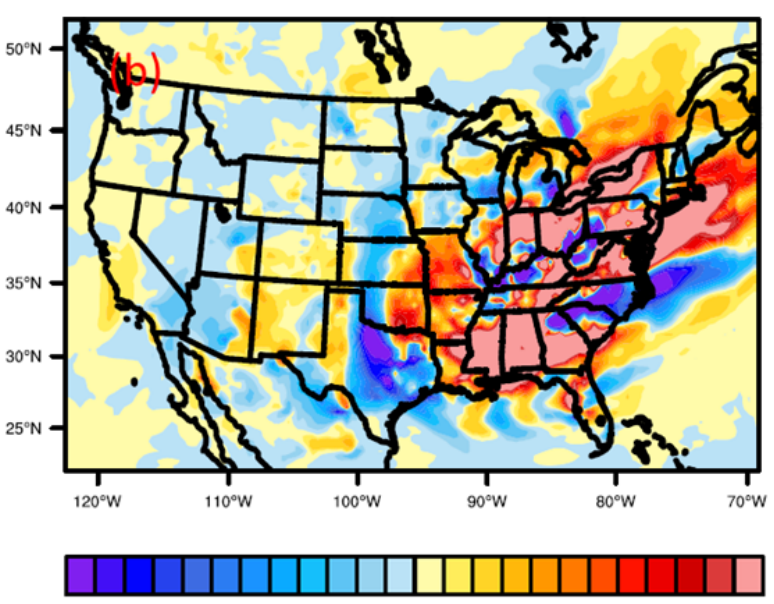

$\begin{array}{lllllllllll}-90 & -70 & -50 & -30 & -10 & 0 & 10 & 30 & 50 & 70 & 90\end{array}$

Fig. 5. Changes in column-integrated (a) $\mathrm{SO}_{4}{ }^{2-}$ and (b) $\mathrm{SO}_{2}$ concentrations in $\mathrm{mmol} \mathrm{m}^{-2}$ due to NPF (N11A1-N01A1). 


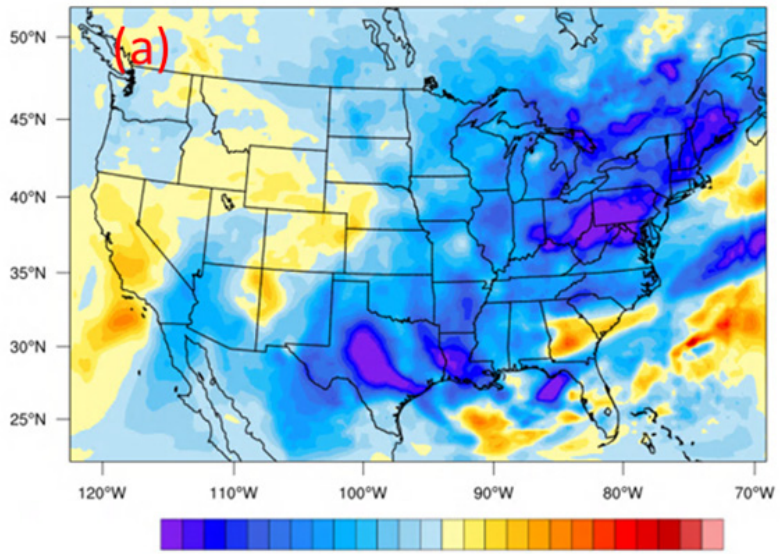

$\begin{array}{lllllllllllll}-24 & -20 & -16 & -12 & -8 & -4 & 0 & 4 & 8 & 12 & 16 & 20 & 24\end{array}$

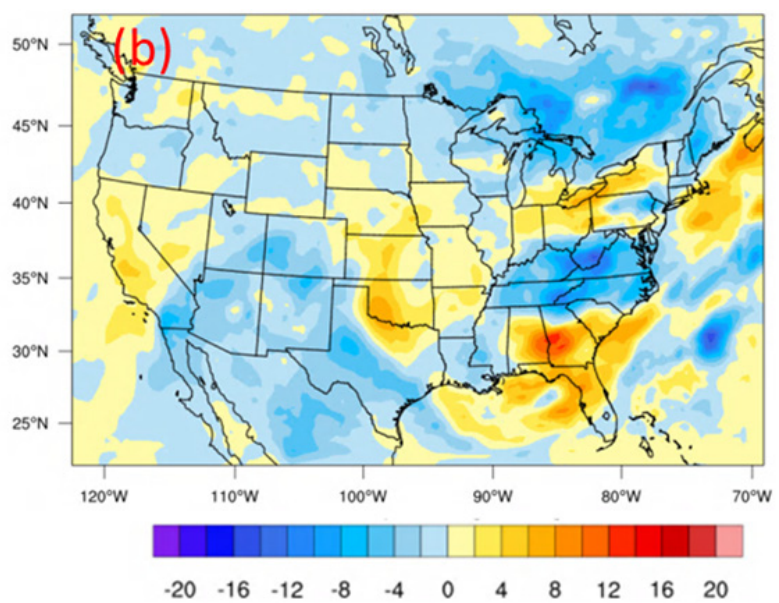

$\begin{array}{lllllllllll}-20 & -16 & -12 & -8 & -4 & 0 & 4 & 8 & 12 & 16 & 20\end{array}$

Fig. 6. Percentage change at $850 \mathrm{~m}$ of (a) $\mathrm{SO}_{4}{ }^{2-}$ and (b) $\mathrm{H}_{2} \mathrm{O}_{2}$, calculated by (N11A1-N01A1)/N01A1 $\times 100 \%$.

Table 5. Midwest mean surface $\mathrm{PM}_{2.5}$ and $\mathrm{SO}_{4}{ }^{2-}$ in the sensitivity test period.

\begin{tabular}{llll}
\hline Concentration $\left(\mu \mathrm{g} \mathrm{m}^{-3}\right)$ & $\mathrm{N} 11 \mathrm{~A} 0$ & $\mathrm{~N} 01 \mathrm{~A} 0$ & $(\mathrm{~N} 11 \mathrm{~A} 0-\mathrm{N} 01 \mathrm{~A} 0) / \mathrm{N} 01 \mathrm{~A} 0$ \\
\hline $\mathrm{PM}_{2.5}$ & 5.23 & 5.29 & $-1.1 \%$ \\
$\mathrm{SO}_{4}{ }^{2-}$ & 1.82 & 1.84 & $-1.1 \%$ \\
\hline
\end{tabular}
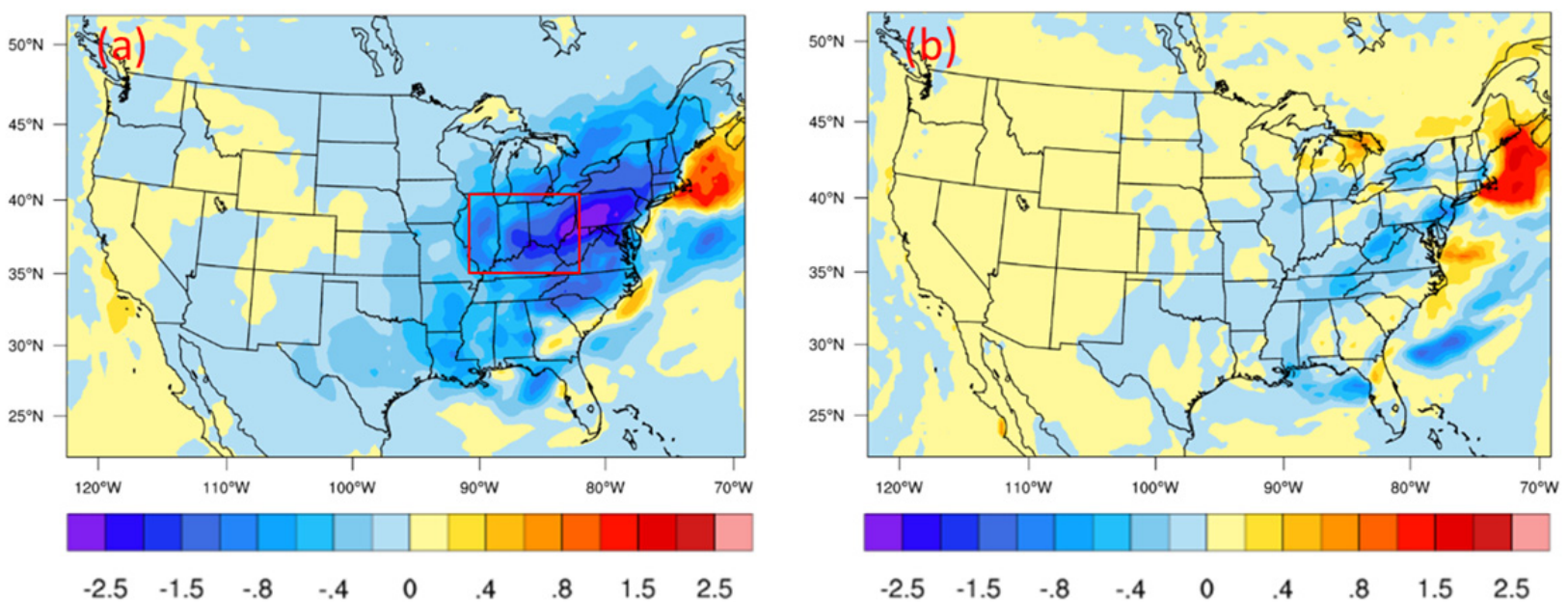

Fig. 7. Absolute change in surface $\mathrm{SO}_{4}{ }^{2-}\left(\mu \mathrm{g} \mathrm{m}{ }^{-2}\right)$ due to NPF while (a) enabling aqueous chemistry (N11A1-N01A1) and (b) while disabling aqueous chemistry (N11A0-N01A0).

in some areas, but these are generally in locations with low $\mathrm{SO}_{2}$ concentrations. In the Midwest, the largest decreases in absolute and percentage $\mathrm{SO}_{4}{ }^{2-}$ concentration are simulated in the most polluted region as shown in the red square in Fig. 7(a). In the following discussion of the influence of cloud chemistry, we limit our analysis to this area.

The decrease in time-averaged mean cloud liquid water is from less frequent cloud occurrence, and from decrease in LWC of simulated clouds. For frequency calculation, we use hourly outputs for layer 1-layer 10. Cloudy grid cells decreased from $3.08 \%$ (N01A1) to $2.44 \%$ (N11A1) with PBL nucleation enabled.

Fig. 8 shows the influence of NPF on the mean aerosol number distribution of the boxed area (Fig. 8(a)), and mean aerosol volume distribution (Figs. 8(b)-8(d)). Panels a-c are from simulations without aqueous chemistry (N11A0 and N01A0) in order to isolate the influence of NPF from the additional effect of aqueous chemistry. The increase in particle number at sizes below $20 \mathrm{~nm}$ is clearly visible (Fig. 8(a)), as is the increase in particle volume in the same size ranges, shown in linear scale (Panel b) and log scale (Panel c). Volume ratios, by bin, are shown in Panel d. For the cases without aqueous chemistry (A0 suffix) there is an increase of particle volume at small sizes, and a decrease at larger sizes. Particle number concentration decreases the most in bin 11 and 12, covering a size range from $100 \mathrm{~nm}$ to $251 \mathrm{~nm}$. The increase of sulfate in the $1-100 \mathrm{~nm}$ range is $0.043 \mu \mathrm{g} \mathrm{m}^{-3}$, while the decrease of sulfate in the 100 $2500 \mathrm{~nm}$ range was $0.146 \mu \mathrm{g} \mathrm{m}^{-3}$. With cloud chemistry turned off, total $\mathrm{PM}_{2.5}$ sulfate still decreases by about $5 \%$ in the boxed area.

With aqueous chemistry active (Fig. 8(d), ratios with the 
A1 suffix), the decrease in particle volume at large sizes is much more pronounced than the cases without aqueous chemistry, and shifts to larger sizes.

NPF has an impact on the distribution of $\mathrm{S}_{\max }$, which can be seen in comparison of N11A1 and N01A1; $S_{\max }$ is the maximum supersaturation reached in rising parcels. $S_{\max }$ is calculated by the parameterization of Abdul-Razzak (2000) and is influenced by the updraft velocity, particle concentration and size, and hygroscopicity. The critical size for activation is about $120 \mathrm{~nm}$ at $S_{\max }=0.25 \%$ and $200 \mathrm{~nm}$ at $\mathrm{S}_{\max }=0.1 \%$, corresponding to bin 11-12 (Kerminen et al., 2012).

Median $\mathrm{S}_{\max }$ for N11A1 and N01A1 runs are $0.153 \%$ and $0.157 \%$, respectively. The distribution (graphed in supplemental material Fig. S10) of $S_{\max }$ values shifts to lower values in N11A1 relative to N01A1, with the frequency of low $\mathrm{S}_{\max }(<0.1 \%)$ at $13.8 \%$ versus $1.8 \%$ respectively. The cause of the changes in $\mathrm{S}_{\max }$ has not been quantified in this work; however, we hypothesize that the decrease of $\mathrm{S}_{\max }$ contributes to the feedback between NPF and reduction in cloud water.

Further showing the importance of $\mathrm{S}_{\max }$ is a sensitivity test with repetition of runs N11A1 and N01A1 with $\mathrm{S}_{\max }$ fixed at $1 \%$. In the two sensitivity tests (ten days including spin up) $\mathrm{S}_{\max }$ was coerced to $1.0 \%$ whenever a cloud is formed in a grid cell. This allowed more particles to be activated with nucleation, and eliminated the large region
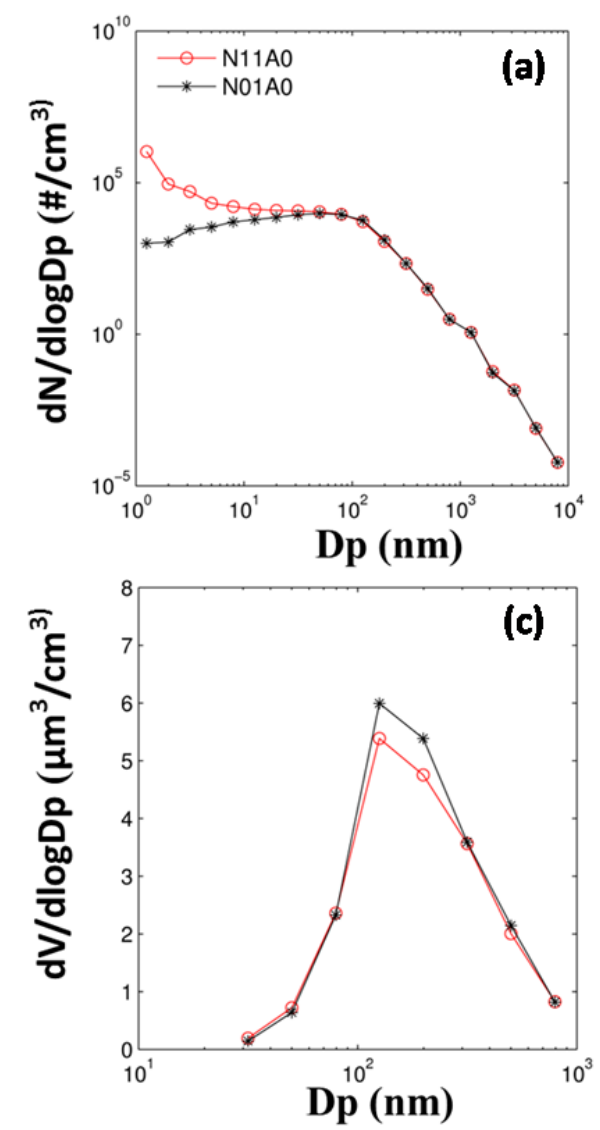

of $\mathrm{SO}_{4}{ }^{2-}$ decrease with NPF on (Fig. S10), replacing it with a mix of small $\mathrm{SO}_{4}{ }^{2-}$ increases and decreases.

As described in the section on meteorological effects, considering grid cells with resolved clouds in both N11A1 and N01A1, turning NPF on (with aqueous chemistry) increases $\mathrm{CN}_{25}$ but decreases CDNC, contributing to the cloud dimming effect. Stratifying this by particle number, we find median sensitivities $\Delta \ln (\mathrm{CDNC}) / \Delta \ln (\mathrm{CN})$, where the $\Delta$ is $\mathrm{N} 11 \mathrm{~A} 1-\mathrm{N} 01 \mathrm{~A} 1$, have positive medians for $\mathrm{CN}$ below $\sim 3000 \mathrm{~cm}^{-3}$, and then have negative medians when $\mathrm{CN}$ is above $\sim 3000 \mathrm{~cm}^{-3}$. The highest frequency of $\mathrm{CN}$ in comparing paired cloudy grid cells between N11A1 and N01A1 contained $3000-4000 \mathrm{~cm}^{-3} \mathrm{CN}$, and had a median $\Delta \ln (\mathrm{CDNC}) / \Delta \ln (\mathrm{CN})$ of -0.35 .

Decreased hygroscopicity of $\mathrm{CCN}$ active particles may also contribute to the decrease in cloud LWC and cloud droplet number in simulations with active NPF. This likely occurs as NPF shifts sulfate mass to smaller particles (through nucleation), and decreases condensational growth of larger particles, as shown in Fig. 8. Condensational growth occurring on primary particles increases their hygroscopicity, facilitating activation.

In addition to liquid-water content, the conversion rate of $\mathrm{SO}_{2}$ to $\mathrm{SO}_{4}{ }^{2-}$ depends on cloud $\mathrm{pH}$ and oxidant concentrations (primarily dissolved $\mathrm{H}_{2} \mathrm{O}_{2}$ and $\mathrm{O}_{3}$ ). The $\mathrm{SO}_{2}-\mathrm{H}_{2} \mathrm{O}_{2}$ reaction is roughly $\mathrm{pH}$ independent while $\mathrm{SO}_{2}$ $\mathrm{O}_{3}$ reaction rates decreases under acidic conditions. Under
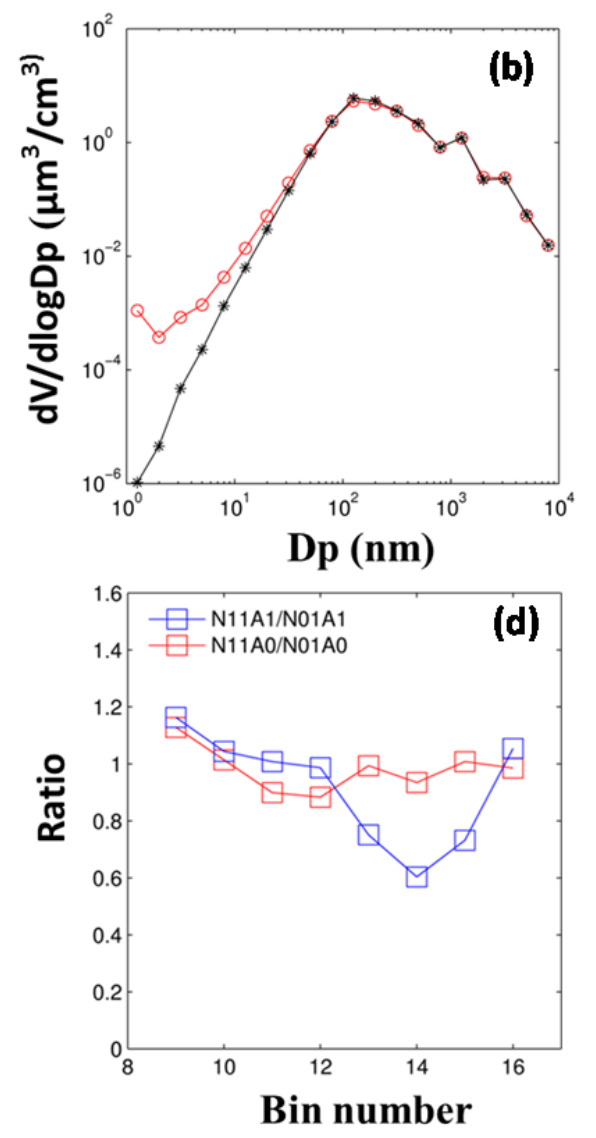

Fig. 8. Midwest particle number (a) and volume (b) distribution without cloud chemistry. Top figures are for all 20 bins. (c) is for particle volume distributions $\left(63.1<\mathrm{D}_{\mathrm{p}}<631 \mathrm{~nm}\right)$, and (d) particle number ratios for bin 9-16. 
both N11A1 and N01A1, over $96 \%$ of clouds had $\mathrm{pH}<5$, consistent with $\mathrm{H}_{2} \mathrm{O}_{2}$ oxidation of $\mathrm{SO}_{2}$ (Hung and Hoffmann, 2015). Fig. 6(b) shows the gas phase $\mathrm{H}_{2} \mathrm{O}_{2}$ at a height of $850 \mathrm{~m}$ above ground. The N11A1 case has higher levels of $\mathrm{H}_{2} \mathrm{O}_{2}$ in most regions of the Midwest, suggesting cloud water is a more important factor than $\mathrm{H}_{2} \mathrm{O}_{2}$ availability in decreasing $\mathrm{SO}_{4}{ }^{2-}$.

\section{Sensitivity to Resolution and Resolved Cumulus Clouds}

The NPF-explicit WRF-Chem model used in this paper considers online aerosol-cloud interactions in resolved clouds only. However, at $36 \mathrm{~km}$ horizontal resolution, both resolved and parameterized clouds are required. The results are tested for sensitivity to horizontal model resolution using a $9 \mathrm{~km}$ horizontal resolution nest within the $36 \mathrm{~km}$ domain. Simulations are ten days with 3-day spin-up for the N11A1 and N01A1 cases without cumulus parameterization, resulting in only grid-resolved clouds. Although the scale is not as fine as convection-permitting models $(<3 \mathrm{~km}$ horizontal resolution; Prein et al., 2015), this sensitivity study represents a spatial scale where cumulus clouds arise in simulation. The 9 and $36 \mathrm{~km}$ results (Figs. S12-S14) are compared for absolute values and changes (BL NPF on vs. off) in surface $\mathrm{SO}_{4}{ }^{2-}, \mathrm{CDNC}$, cloud $\mathrm{LWC}$, and total precipitation. Values and spatial patterns were similar with the exceptions of precipitation (higher at $9 \mathrm{~km}$ resolution) and absolute surface $\mathrm{SO}_{4}{ }^{2-}$ concentration (lower in $9 \mathrm{~km}$ simulation). Percentage changes in sulfate are similar in the $9 \mathrm{~km}$ simulation even though absolute concentrations are lower. WRF-Chem v3.8 and v3.9 permit cloud-aerosol interactions in sub-grid-scale convective clouds as described by Berg et al. (2015) and replication of our finding in nucleation-explicit variants of these later releases (and in other models) is an important next step. Berg et al. (2015) conducted sensitivity studies with and without aqueous chemistry in WRF-Chem including aerosol interaction with convective clouds, and report on changes to both sources and sinks of $\mathrm{SO}_{4}{ }^{2-}$, but do not extend the work to also include sensitivity to NPF.

\section{Sensitivity to Biogenic Secondary Aerosol}

A biogenic SOA sensitivity simulation employed a simplified biogenic SOA treatment adapted from the WRF-Chem NPF study of Cui et al. (2014). Fixed fractions of isoprene (4\%), $\alpha$-pinene (15\%) and limonene (15\%) are converted to biogenic SOA and condensed onto preexisting particles in proportion to the Fuchs corrected surface area of each aerosol section. For computational efficiency, the partitioning is assumed to be irreversibly to the aerosol phase. OC increases across the domain, and especially in the southeast U.S. Midwest mean OC increases from 0.49 to $1.39 \mu \mathrm{g} \mathrm{m}^{-3}$ due to the biogenic SOA (Fig. S16). Decreases in $\mathrm{SO}_{4}{ }^{2-}, \mathrm{CDNC}$ and cloud water still occur in the eastern U.S., in patterns and quantities very similar to the base simulations with no biogenic SOA (Fig. S17-S18).

\section{Conceptual Model}

A conceptual model of the processes in NPF explicit WRF-Chem leading to the influence of NPF on inorganic particle mass, and modified through a cloud processing feedback, is drawn in Fig. 9. PBL nucleation increases the number of ultrafine particles, shifting the size distribution to smaller sizes, increasing mass at sizes below $100 \mathrm{~nm}$, and decreasing mass at sizes above about $100 \mathrm{~nm}$. The modified size distribution of aerosol particles leads to changes in cloud properties, specifically lower CDNC, lower cloud liquid water path (LWP), depressed $\mathrm{S}_{\max }$, and lower COD. Model sensitivity tests indicate that the changes in overall sulfate mass are due to a feedback process where reduction of cloud liquid water causes less $\mathrm{SO}_{4}{ }^{2-}$ formation via aqueous chemistry. Changes in biogenic emissions, shortwave radiation, and $\mathrm{OH}$ concentrations contribute. Not shown in Fig. 9 are the (relatively minor) changes in PBL height (increasing on average in areas of high inorganic PM), and their effect of decreasing all surface pollutants such as $\mathrm{CO}$, primary organic carbon, black carbon, and inorganic PM.

\section{CONCLUSION}

This is the first study quantifying the interactions between PBL nucleation, meteorology, and air quality. We have demonstrated a link between NPF and reduced $\mathrm{SO}_{2}-\mathrm{SO}_{4}{ }^{2-}$ conversion over the Midwestern and Eastern U.S. in summer that is moderated through cloud activation and aqueous chemical processes. Furthermore, for the location and time period simulated, resolving NPF led to an indirect effect counter to the usual direction-with NPF causing fewer and dimmer clouds, supporting the results of Sullivan et al. (2018). The result is novel because while there are studies that have one or more key features of our work (explicit treatment of the nuclei mode from 1 to $10 \mathrm{~nm}$, clouds coupled to meteorology and resolved clouds coupled to primary and secondary aerosols, biogenic emissions that are coupled online with radiation and meteorology, and sensitivity tests where aqueous chemistry and PBL nucleation are independently activated or not activated), a literature search found no studies reporting all of these features.

In our simulations, which predicted most air pollutants at a level of accuracy similar to that of contemporary models, some features of previous studies were reproduced, such as the enhancement of $\mathrm{CN}$ concentrations and $\mathrm{CCN}$ concentrations at high supersaturations. More interestingly, the concentration of CCN at low supersaturations decreased, and the inclusion of PBL nucleation changed meteorological and air pollution variables, often in unexpected ways (reductions in $\mathrm{PM}_{2.5} \mathrm{SO}_{4}{ }^{2-}$; reductions in the cloud frequency, cloud optical depth, and cloud droplet number concentration; etc.). Sensitivity tests demonstrated that aqueous chemistry combines with PBL nucleation to form a feedback loop, drawn in Fig. 9, resulting in less frequent clouds and lower average cloud water content. This in turn reduces the amount of volume available for aqueous chemical reactions and further reduces sulfate production. Changes in $\mathrm{OH}$ and biogenic VOCs may also be involved. Alternative hypotheses for the $\mathrm{SO}_{4}{ }^{2}$ decrease (cloud droplet $\mathrm{pH}$ changes, changes in $\mathrm{H}_{2} \mathrm{O}_{2}$, changes in dry and wet deposition, and boundary layer height increases) are insufficient for explaining the 


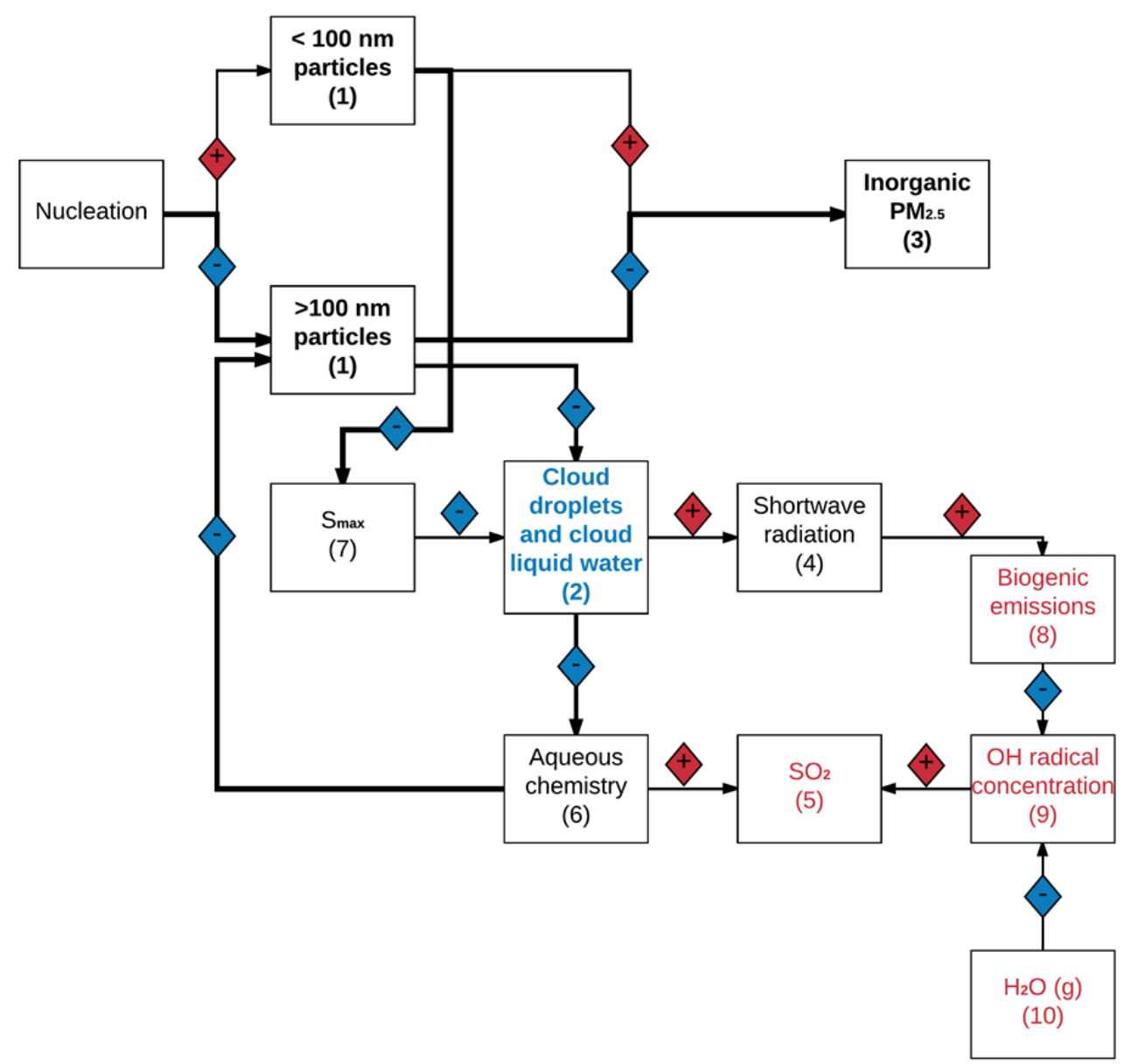

Fig. 9. Selected features leading to decrease in inorganic $\mathrm{PM}_{2.5}$. Colors indicate phase as aerosols (bold black), clouds (blue) and gases (red). (1) active nuclei production increases ultrafine particles and (through decreased condensation of $\mathrm{H}_{2} \mathrm{SO}_{4}$ ) decreases accumulation mode particles (Fig. 8); (2) CDNC and cloud LWC decrease; (3) in areas of peak concentration, $\mathrm{PM}_{2.5}$ and $\mathrm{SO}_{4}$ decrease (Figs. 2 and 7); (4) short wave radiation increases (Fig. 4); (5) $\mathrm{SO}_{2}$ concentrations increase (Fig. 5); (6) conversion of $\mathrm{SO}_{2}$ to $\mathrm{SO}_{4}$ by aqueous chemistry decreases (Fig. 7); (7) the distribution of $\mathrm{S}_{\max }$ shifts to lower values with NPF; and (8) isoprene concentrations are increased somewhat in key locations with NPF; (9) Decrease of OH radical concentration (Fig. S8); (10) Decrease of water vapor concentration (Fig. S8).

modeled results. Limitations in the simulations with regard to resolution (36 km and sub-grid clouds not coupled with aerosols) and no SOA were addressed with sensitivity runs, which showed the persistence of key sulfate and cloud effects. When compared to observations within the domain, simulated $\mathrm{CN}$ concentrations were generally higher, which indicates our findings on air quality and meteorological feedback processes might be an upper limit.

These substantial effects of NPF on sulfate and clouds only appear in our simulations with the simultaneous coupling of NPF, aerosols, aqueous chemistry, and meteorology. Replication in other fully coupled models is needed across a variety of resolution-season combinations, including in models with state-of-science treatments of SOA and aerosol-cloud-radiation interactions in cumulus clouds. Furthermore, observational or experimental evidence of these feedback loops is also needed. With these caveats, we have found a potentially important feedback process relevant to air quality, weather forecasting, and aerosolcloud-climate studies.

\section{ACKNOWLEDGMENTS}

This research has been supported by NSF grant ATM0748602, funds from the Center for Global and Regional Environmental Research (CD, AP, CS), and NASA NNX11AI52G (SS). HM was supported by by the Japan Society for the Promotion of Science (JSPS), the Ministry of Education, Culture, Sports, Science, and Technology and the Japan Society for the Promotion of Science (MEXT/JSPS) KAKENHI (JP26740014, JP17H04709, JP26241003, and JP16H01770), MEXT Green Network of Excellence (GRENE) and Arctic Challenge for Sustainability (ArCS) projects, and the global environment research funds of the Ministry of the Environment, Japan (2-1403, 2-1703) (HM). We thank Yuyan Cui and Alma Hodzic for correspondence regarding Cui et al. (2014).

\section{SUPPLEMENTARY MATERIAL}

Supplementary data associated with this article can be 
found in the online version at http://www.aaqr.org.

\section{REFERENCES}

Abdul-Razzak, H. and Ghan, S.J. (2000). A parameterization of aerosol activation: 2. Multiple aerosol types. J. Geophys. Res. 105: 6837-6844.

Albrecht, B.A. (1989). Aerosols, cloud microphysics, and fractional cloudiness. Science 245: 1227-1230.

Archer-Nicholls, S., Lowe, D., Utembe, S., Allan, J., Zaveri, R.A., Fast, J.D., Hodnebrog, Ø., Denier van der Gon, H. and McFiggans, G. (2014). Gaseous chemistry and aerosol mechanism developments for version 3.5.1 of the online regional model, WRF-Chem. Geosci. Model Dev. 7: 2557-2579.

Asmi, A., Collaud Coen, M., Ogren, J., Andrews, E., Sheridan, P., Jefferson, A., Weingartner, E., Baltensperger, U., Bukowiecki, N. and Lihavainen, H. (2013). Aerosol decadal trends-Part 2: In-situ aerosol particle number concentrations at GAW and ACTRIS stations. Atmos. Chem. Phys. 13: 895-916.

Baranizadeh, E., Murphy, B.N., Julin, J., Falahat, S., Reddington, C.L., Arola, A., Ahlm, L., Mikkonen, S., Fountoukis, C., Patoulias, D., Minikin, A., Hamburger, T., Laaksonen, A., Pandis, S.N., Vehkamäki, H., Lehtinen, K.E.J. and Riipinen, I. (2016). Implementation of stateof-the-art ternary new-particle formation scheme to the regional chemical transport model PMCAMX-UF in Europe. Geosci. Model Dev. 9: 2741-2754.

Berg, L.K., Shrivastava, M., Easter, R.C., Fast, J.D., Chapman, E.G., Liu, Y. and Ferrare, R.A. (2015). A new WRF-Chem treatment for studying regional-scale impacts of cloud processes on aerosol and trace gases in parameterized cumuli. Geosci. Model Dev. 8: 409-429.

Bullard, R.L., Singh, A., Anderson, S.M., Lehmann, C.M. and Stanier, C.O. (2017). 10-month characterization of the aerosol number size distribution and related air quality and meteorology at the bondville, IL Midwestern background site. Atmos. Environ. 154: 348-361.

Chen, D.S., Ma, X., Xie, X., Wei, P., Wen, W., Xu, T.T., Yang, N., Gao, Q.X., Shi, H.D., Guo, X.R., Li, Y., Zhou, Y. and Lang, J.L. (2015). Modelling the effect of aerosol feedbacks on the regional meteorology factors over China. Aerosol Air Qual. Res. 15: 1559-1579.

Chen, F. and Dudhia, J. (2001). Coupling an advanced land surface-hydrology model with the Penn State-NCAR MM5 modeling system. Part I: Model implementation and sensitivity. Mon. Weather Rev. 129: 569-585.

Chou, M.D. and Suarez, M.J. (1994). An efficient thermal infrared radiation parameterization for use in general circulation models. NASA Tech. Memo. 104606.

Croft, B., Martin, R.V., Leaitch, W.R., Tunved, P., Breider, T.J., D'Andrea, S.D. and Pierce, J.R. (2016). Processes controlling the annual cycle of arctic aerosol number and size distributions. Atmos. Chem. Phys. 16: 3665-3682.

Cui, Y., Hodzic, A., Smith, J., Ortega, J., Brioude, J., Matsui, H., Levin, E., Turnipseed, A., Winkler, P. and de Foy, B. (2014). Modeling ultrafine particle growth at a pine forest site influenced by anthropogenic pollution during BEACHON-RoMBAS 2011. Atmos. Chem. Phys. 14: 11011-11029.

Emery, C., Liu, Z., Russell, A.G., Odman, M.T., Yarwood, G. and Kumar, N. (2017). Recommendations on statistics and benchmarks to assess photochemical model performance. J. Air Waste Manage. Assoc. 67: 582-598.

Emmons, S. (2010). Description and evaluation of the Model for Ozone and Related chemical Tracers, version 4 (MOZART-4). Geosci. Model Dev. 3: 43-67.

EPA (2015) Preparation of emissions inventories for the version 6.2, 2011 emissions modeling platform, https://ww w.epa.gov/sites/production/files/2015-10/documents/20 11v6_2_2017_2025_emismod_tsd_aug2015.pdf, Last Access: 23 Nov. $201 \overline{6}$.

Fahey, K.M. and Pandis, S.N. (2001). Optimizing model performance: Variable size resolution in cloud chemistry modeling. Atmos. Environ. 35: 4471-4478.

Fan, J., Wang, Y., Rosenfeld, D. and Liu, X. (2016). Review of aerosol-cloud interactions: Mechanisms, significance, and challenges. J. Atmos. Sci.73: 4221-4252.

Farmer, D.K., Cappa, C.D. and Kreidenweis, S.M. (2015). Atmospheric processes and their controlling influence on cloud condensation nuclei activity. Chem. Rev. 115: 4199-4217.

Fast, J.D., Gustafson, W.I., Easter, R.C., Zaveri, R.A., Barnard, J.C., Chapman, E.G., Grell, G.A. and Peckham, S.E. (2006). Evolution of ozone, particulates, and aerosol direct radiative forcing in the vicinity of houston using a fully coupled meteorology-chemistry-aerosol model. J. Geophys. Res. 111: D21305.

Forkel, R., Brunner, D., Baklanov, A., Balzarini, A., Hirtl, M., Honzak, L., Jiménez-Guerrero, P., Jorba, O., Pérez, J. and San José, R. (2016). A multi-model case study on aerosol feedbacks in online coupled chemistry-meteorology models within the cost action ES1004 EuMetChem, In Air pollution modeling and its application XXIV, Springer, pp. 23-28.

Gong, S., Barrie, L. and Lazare, M. (2002). Canadian Aerosol Module (CAM): A size-segregated simulation of atmospheric aerosol processes for climate and air quality models 2 . Global sea-salt aerosol and its budgets. J. Geophys. Res. 107: 4779.

Gordon, H., Kirkby, J., Baltensperger, U., Bianchi, F., Breitenlechner, M., Curtius, J., Dias, A., Dommen, J., Donahue, N.M. and Dunne, E.M. (2017). Causes and importance of new particle formation in the present-day and pre-industrial atmospheres. J. Geophys. Res. 122: 8739-8760.

Grell, G.A. and Dévényi, D. (2002). A generalized approach to parameterizing convection combining ensemble and data assimilation techniques. Geophys. Res. Lett. 29: 3831-38-34.

Grell, G.A., Peckham, S.E., Schmitz, R., McKeen, S.A., Frost, G., Skamarock, W.C. and Eder, B. (2005). Fully coupled "online" chemistry within the WRF model. Atmos. Environ. 39: 6957-6975.

Guenther, C. (2006). Estimates of global terrestrial isoprene emissions using MEGAN (Model of Emissions of Gases and Aerosols from Nature). Atmos. Chem. Phys. 6: 3181- 
3210.

Hong, S.Y., Noh, Y. and Dudhia, J. (2006). A new vertical diffusion package with an explicit treatment of entrainment processes. Mon. Weather Rev. 134: 23182341.

Hung, H.M. and Hoffmann, M.R. (2015). Oxidation of gas-phase $\mathrm{SO}_{2}$ on the surfaces of acidic microdroplets: Implications for sulfate and sulfate radical anion formation in the atmospheric liquid phase. Environ. Sci. Technol. 49: 13768-13776.

Jacobson, M.Z., Turco, R.P., Jensen, E.J. and Toon, O.B. (1994). Modeling coagulation among particles of different composition and size. Atmos. Environ. 28: 1327-1338.

Jung, J., Fountoukis, C., Adams, P.J. and Pandis, S.N. (2010). Simulation of in situ ultrafine particle formation in the Eastern United States using PMCAMX-UP. $J$. Geophys. Res. 115: D03203.

Karydis, V.A., Kumar, P., Barahona, D., Sokolik, I.N. and Nenes, A. (2011). On the effect of dust particles on global cloud condensation nuclei and cloud droplet number. J. Geophys. Res. 116: D23204.

Kazil, J., Stier, P., Zhang, K., Quaas, J., Kinne, S., O'donnell, D., Rast, S., Esch, M., Ferrachat, S. and Lohmann, U. (2010). Aerosol nucleation and its role for clouds and earth's radiative forcing in the aerosolclimate model ECHAM5-HAM. Atmos. Chem. Phys. 10: 10733-10752.

Kerminen, V.M., Paramonov, M., Anttila, T., Riipinen, I., Fountoukis, C., Korhonen, H., Asmi, E., Laakso, L., Lihavainen, H., Swietlicki, E., Svenningsson, B., Asmi, A., Pandis, S.N., Kulmala, M. and Petäjä, T. (2012). Cloud condensation nuclei production associated with atmospheric nucleation: A synthesis based on existing literature and new results. Atmos. Chem. Phys. 12: 12037-12059.

Kuang, C., McMurry, P.H., McCormick, A.V. and Eisele, F. (2008). Dependence of nucleation rates on sulfuric acid vapor concentration in diverse atmospheric locations. J. Geophys. Res. 113: D10209.

Kulmala, M., Pirjola, L. and Makela, J.M. (2000). Stable sulphate clusters as a source of new atmospheric particles. Nature 404: 66-69.

Kulmala, M., Lehtinen, K.E.J. and Laaksonen, A. (2006). Cluster activation theory as an explanation of the linear dependence between formation rate of $3 \mathrm{~nm}$ particles and sulphuric acid concentration. Atmos. Chem. Phys. 6: 787-793.

Li, G., Zavala, M., Lei, W., Tsimpidi, A., Karydis, V., Pandis, S.N., Canagaratna, M. and Molina, L. (2011). Simulations of organic aerosol concentrations in Mexico City using the WRF-Chem model during the MCMA2006/MILAGRO campaign. Atmos. Chem. Phys. 11: 3789-3809.

Lin, Y.L., Farley, R.D. and Orville, H.D. (1983). Bulk parameterization of the snow field in a cloud model. $J$. Clim. Appl. Meteorol. 22: 1065-1092.

Liu, X.Y., Zhang, Y., Zhang, Q. and He, K.B. (2016). Application of online-coupled WRF/Chem-MADRID in East Asia: Model evaluation and climatic effects of anthropogenic aerosols. Atmos. Environ. 124: 321-336.

Lucas, D.D. and Akimoto, H. (2006). Evaluating aerosol nucleation parameterizations in a global atmospheric model. Geophys. Res. Lett. 33: L10808.

Luo, G. and Yu, F. (2011). Simulation of particle formation and number concentration over the Eastern United States with the WRF-Chem + APM model. Atmos. Chem. Phys. 11: 11521-11533.

Lupascu, A., Easter, R., Zaveri, R., Shrivastava, M., Pekour, M., Tomlinson, J., Yang, Q., Matsui, H., Hodzic, A. and Zhang, Q. (2015). Modeling particle nucleation and growth over northern California during the 2010 CARES campaign. Atmos. Chem. Phys. 15: 12283-12313.

Makar, P., Gong, W., Hogrefe, C., Zhang, Y., Curci, G., Žabkar, R., Milbrandt, J., Im, U., Balzarini, A. and Baró, R. (2015). Feedbacks between air pollution and weather, Part 2: Effects on chemistry. Atmos. Environ. 115: 499526.

Mann, G.W., Carslaw, K.S., Reddington, C.L., Pringle, K.J., Schulz, M., Asmi, A., Spracklen, D.V., Ridley, D.A., Woodhouse, M.T. and Lee, L.A. (2014). Intercomparison and evaluation of global aerosol microphysical properties among AeroCom models of a range of complexity. Atmos. Chem. Phys. 14: 4679-4713.

Mashayekhi, R. and Sloan, J. (2014). Effects of aerosols on precipitation in North-eastern North America. Atmos. Chem. Phys. 14: 5111-5125.

Matsui, H., Koike, M., Kondo, Y., Takegawa, N., Wiedensohler, A., Fast, J.D. and Zaveri, R.A. (2011). Impact of new particle formation on the concentrations of aerosols and cloud condensation nuclei around Beijing. J. Geophys. Res. 116: D19208.

Matsui, H. and Mahowald, N. (2017). Development of a global aerosol model using a two-dimensional sectional method: 2. Evaluation and sensitivity simulations. $J$. Adv. Model. Earth Syst. 9: 1887-1920.

Matsui, H., Koike, M., Takegawa, N., Kondo, Y., Takami, A., Takamura, T., Yoon, S.J., Kim, S.W., Lim, H.C. and Fast, J.D. (2013). Spatial and temporal variations of new particle formation in East Asia using an NPF-explicit WRF-Chem model: North-south contrast in new particle formation frequency. J. Geophys. Res. 118: 11647611663.

Merikanto, J., Spracklen, D.V., Mann, G.W., Pickering, S.J. and Carslaw, K.S. (2009). Impact of nucleation on global CCN. Atmos. Chem. Phys. 9: 8601-8616.

Mlawer, E.J., Taubman, S.J., Brown, P.D., Iacono, M.J. and Clough, S.A. (1997). Radiative transfer for inhomogeneous atmospheres: RRTM, a validated correlated-k model for the longwave. J. Geophys. Res. 102: 16663-16682.

Monahan, E.C., Spiel, D.E. and Davidson, K.L. (1986). A model of marine aerosol generation via whitecaps and wave disruption, In Oceanic whitecaps: And their role in air-sea exchange processes, Monahan, E.C. and Niocaill, G.M. (Eds.), Springer Netherlands, Dordrecht, pp. 167-174.

Moore, R., Karydis, V., Capps, S., Lathem, T. and Nenes, A. (2013). Droplet number uncertainties associated with 
CCN: An assessment using observations and a global model adjoint. Atmos. Chem. Phys. 13: 4235-4251.

Morris, R.E., McNally, D.E., Tesche, T.W., Tonnesen, G., Boylan, J.W. and Brewer, P. (2005). Preliminary evaluation of the community multiscale air quality model for 2002 over the Southeastern United States. J. Air Waste Manage. Assoc. 55: 1694-1708.

Myhre, G., Aas, W., Cherian, R., Collins, W., Faluvegi, G., Flanner, M., Forster, P., Hodnebrog, Ø., Klimont, Z., Lund, M.T., Mülmenstädt, J., Lund Myhre, C., Olivié, D., Prather, M., Quaas, J., Samset, B.H., Schnell, J.L., Schulz, M., Shindell, D., Skeie, R.B., Takemura, T. and Tsyro, S. (2017). Multi-model simulations of aerosol and ozone radiative forcing due to anthropogenic emission changes during the period 1990-2015. Atmos. Chem. Phys. 17: 2709-2720.

Myhre, G., Samset, B., Schulz, M., Balkanski, Y., Bauer, S., Berntsen, T., Bian, H., Bellouin, N., Chin, M. and Diehl, T. (2013). Radiative forcing of the direct aerosol effect from AeroCom Phase II simulations. Atmos. Chem. Phys. 13: 1853-1877.

Paasonen, P., Asmi, A., Petäjä, T., Kajos, M.K., Äijälä, M., Junninen, H., Holst, T., Abbatt, J.P., Arneth, A. and Birmili, W. (2013). Warming-induced increase in aerosol number concentration likely to moderate climate change. Nat. Geosci. 6: 438-442.

Pettibone, A.J. (2009). Toward a better understanding of new particle formation. $\mathrm{PhD}$ dissertation, University of Iowa, USA.

Pincus, R. and Baker, M.B. (1994). Effect of precipitation on the albedo susceptibility of clouds in the marine boundary layer. Nature 372: 250-252.

Prein, A.F., Langhans, W., Fosser, G., Ferrone, A., Ban, N., Goergen, K., Keller, M., Tölle, M., Gutjahr, O. and Feser, F. (2015). A review on regional convectionpermitting climate modeling: Demonstrations, prospects, and challenges. Rev. Geophys. 53: 323-361.

Pryor, S., Spaulding, A. and Barthelmie, R. (2010). New particle formation in the Midwestern USA: Event characteristics, meteorological context and vertical profiles. Atmos. Environ. 44: 4413-4425.

Quaas, J., Ming, Y., Menon, S., Takemura, T., Wang, M., Penner, J.E., Gettelman, A., Lohmann, U., Bellouin, N. and Boucher, O. (2009). Aerosol indirect effects-general circulation model intercomparison and evaluation with satellite data. Atmos. Chem. Phys. 9: 8697-8717.

Rosenfeld, D., Lohmann, U., Raga, G.B., O'Dowd, C.D., Kulmala, M., Fuzzi, S., Reissell, A. and Andreae, M.O. (2008). Flood or drought: How do aerosols affect precipitation? Science 321: 1309-1313.

Scott, C.E., Spracklen, D.V., Pierce, J.R., Riipinen, I., D'Andrea, S.D., Rap, A., Carslaw, K.S., Forster, P.M., Artaxo, P., Kulmala, M., Rizzo, L.V., Swietlicki, E., Mann, G.W. and Pringle, K.J. (2015). Impact of gas-toparticle partitioning approaches on the simulated radiative effects of biogenic secondary organic aerosol. Atmos. Chem. Phys. 15: 12989-13001.

Seinfeld, J.H., Bretherton, C., Carslaw, K.S., Coe, H., DeMott, P.J., Dunlea, E.J., Feingold, G., Ghan, S.,
Guenther, A.B. and Kahn, R. (2016). Improving our fundamental understanding of the role of aerosol-cloud interactions in the climate system. Proc. Natl. Acad. Sci. U.S.A. 113: 5781-5790.

Shaw, W.J., Allwine, K.J., Fritz, B.G., Rutz, F.C., Rishel, J.P. and Chapman, E.G. (2008). An evaluation of the wind erosion module in DUSTRAN. Atmos. Environ. 42: 1907-1921.

Sheridan, P., Andrews, E., Ogren, J., Tackett, J. and Winker, D. (2012). Vertical profiles of aerosol optical properties over central Illinois and comparison with surface and satellite measurements. Atmos. Chem. Phys. 12: $11695-11721$.

Shrivastava, M., Berg, L.K., Fast, J.D., Easter, R.C., Laskin, A., Chapman, E.G., Gustafson, W.I., Liu, Y. and Berkowitz, C.M. (2013). Modeling aerosols and their interactions with shallow cumuli during the 2007 CHAPS field study. J. Geophys. Res. 118: 1343-1360.

Simon, H., Baker, K.R. and Phillips, S. (2012). Compilation and interpretation of photochemical model performance statistics published between 2006 and 2012. Atmos. Environ. 61: 124-139.

Spak, S.N. and Holloway, T. (2009). Seasonality of speciated aerosol transport over the Great Lakes region. J. Geophys. Res. 114: D08302.

Spracklen, D.V., Carslaw, K.S., Kulmala, M., Kerminen, V.M., Mann, G.W. and Sihto, S.L. (2006). The contribution of boundary layer nucleation events to total particle concentrations on regional and global scales. Atmos. Chem. Phys. 6: 5631-5648.

Spracklen, D.V., Carslaw, K.S., Merikanto, J., Mann, G.W., Reddington, C.L., Pickering, S., Ogren, J.A., Andrews, E., Baltensperger, U., Weingartner, E., Boy, M., Kulmala, M., Laakso, L., Lihavainen, H., Kivekäs, N., Komppula, M., Mihalopoulos, N., Kouvarakis, G., Jennings, S.G., O'Dowd, C., Birmili, W., Wiedensohler, A., Weller, R., Gras, J., Laj, P., Sellegri, K., Bonn, B., Krejci, R., Laaksonen, A., Hamed, A., Minikin, A., Harrison, R.M., Talbot, R. and Sun, J. (2010). Explaining global surface aerosol number concentrations in terms of primary emissions and particle formation. Atmos. Chem. Phys. 10: 4775-4793.

Sullivan, R.C., Crippa, P., Matsui, H., Leung, L.R., Zhao, C., Thota, A. and Pryor, S.C. (2018). New particle formation leads to cloud dimming. npj Clim. Atmos. Sci. 1: 9 .

Toon, O.B., Maring, H., Dibb, J., Ferrare, R., Jacob, D.J., Jensen, E.J., Luo, Z.J., Mace, G.G., Pan, L.L. and Pfister, L. (2016). Planning, implementation, and scientific goals of the studies of emissions and atmospheric composition, clouds and climate coupling by regional surveys (SEAC4RS) field mission. J. Geophys. Res. 121: 4967-5009.

Tsigaridis, K., Daskalakis, N., Kanakidou, M., Adams, P., Artaxo, P., Bahadur, R., Balkanski, Y., Bauer, S., Bellouin, N. and Benedetti, A. (2014). The aerocom evaluation and intercomparison of organic aerosol in global models. Atmos. Chem. Phys. 14: 10845-10895.

Tuccella, P., Curci, G., Visconti, G., Bessagnet, B., Menut, 
L. and Park, R.J. (2012). Modeling of gas and aerosol with WRF/Chem over Europe: Evaluation and sensitivity study. J. Geophys. Res. 117: D03303.

Twomey, S. (1977). The influence of pollution on the shortwave albedo of clouds. J. Atmos. Sci. 34: 11491152.

Wagner, N., Brock, C., Angevine, W., Beyersdorf, A., Campuzano-Jost, P., Day, D., de Gouw, J., Diskin, G., Gordon, T. and Graus, M. (2015). In situ vertical profiles of aerosol extinction, mass, and composition over the Southeast United States during SENEX and SEAC4RS: Observations of a modest aerosol enhancement aloft. Atmos. Chem. Phys. 15: 7085-7102.

Wang, H., Easter, R.C., Rasch, P.J., Wang, M., Liu, X., Ghan, S.J., Qian, Y., Yoon, J.H., Ma, P.L. and Vinoj, V. (2013). Sensitivity of remote aerosol distributions to representation of cloud-aerosol interactions in a global climate model. Geosci. Model Dev. 6: 765-782.

Wang, M. and Penner, J. (2009). Aerosol indirect forcing in a global model with particle nucleation. Atmos. Chem. Phys. 9: 239-260.

Wang, M., Ghan, S., Ovchinnikov, M., Liu, X., Easter, R., Kassianov, E., Qian, Y. and Morrison, H. (2011). Aerosol indirect effects in a multi-scale aerosol-climate model PNNL-MMF. Atmos. Chem. Phys. 11: 5431-5455.

Westervelt, D.M., Pierce, J.R. and Adams, P.J. (2014). Analysis of feedbacks between nucleation rate, survival probability and cloud condensation nuclei formation. Atmos. Chem. Phys. 14: 5577-5597.

Wexler, A.S., Lurmann, F.W. and Seinfeld, J.H. (1994). Modelling urban and regional aerosols-I. Model development. Atmos. Environ. 28: 531-546.

Wild, O., Zhu, X. and Prather, M.J. (2000). Fast-J: Accurate simulation of in- and below-cloud photolysis in tropospheric chemical models. J. Atmos. Chem. 37: 245-282.

Yahya, K., Zhang, Y. and Vukovich, J.M. (2014). Realtime air quality forecasting over the southeastern united states using WRF/Chem-MADRID: Multiple-year assessment and sensitivity studies. Atmos. Environ. 92: 318-338.

Yang, Q., W. I. Gustafson, J., Fast, J.D., Wang, H., Easter, R.C., Morrison, H., Lee, Y.N., Chapman, E.G., Spak, S.N. and Mena-Carrasco, M.A. (2011). Assessing regional scale predictions of aerosols, marine stratocumulus, and their interactions during VOCALS-REx using WRF-
Chem. Atmos. Chem. Phys. 11: 11951-11975.

Yu, F. and Luo, G. (2009). Simulation of particle size distribution with a global aerosol model: Contribution of nucleation to aerosol and $\mathrm{CCN}$ number concentrations. Atmos. Chem. Phys. 9: 7691-7710.

$\mathrm{Yu}, \mathrm{F}$. (2011). A secondary organic aerosol formation model considering successive oxidation aging and kinetic condensation of organic compounds: Global scale implications. Atmos. Chem. Phys. 11: 1083-1099.

$\mathrm{Yu}$, F. and Hallar, A. (2014). Difference in particle formation at a mountaintop location during spring and summer: Implications for the role of sulfuric acid and organics in nucleation. J. Geophys. Res. 119: 1224612255.

Yu, F., Luo, G., Pryor, S.C., Pillai, P.R., Lee, S.H., Ortega, J., Schwab, J.J., Hallar, A.G., Leaitch, W.R., Aneja, V.P., Smith, J.N., Walker, J.T., Hogrefe, O. and Demerjian, K.L. (2015). Spring and summer contrast in new particle formation over nine forest areas in North America. Atmos. Chem. Phys. 15: 13993-14003.

Yue, D.L., Zhong, L.J., Zhang, T., Shen, J., Yuan, L., Ye, S.Q., Zhou, Y. and Zeng, L.M. (2016). Particle growth and variation of cloud condensation nucleus activity on polluted days with new particle formation: A case study for regional air pollution in the PRD region, China. Aerosol Air Qual. Res. 16: 323-335.

Zaveri, R.A., Easter, R.C., Fast, J.D. and Peters, L.K. (2008). Model for simulating aerosol interactions and chemistry (MOSAIC). J. Geophys. Res. 113: D13204.

Zhang, R., Khalizov, A., Wang, L., Hu, M. and Xu, W. (2011). Nucleation and growth of nanoparticles in the atmosphere. Chem. Rev. 112: 1957-2011.

Zhang, Y., McMurry, P.H., Yu, F. and Jacobson, M.Z. (2010a). A comparative study of nucleation parameterizations: 1. Examination and evaluation of the formulations. J. Geophys. Res. 115: D20212.

Zhang, Y., Wen, X.Y. and Jang, C. (2010b). Simulating chemistry-aerosol-cloud-radiation-climate feedbacks over the continental US using the online-coupled weather research forecasting model with chemistry (WRF/Chem). Atmos. Environ. 44: 3568-3582.

Received for review, May 7, 2018 Revised, September 2, 2018 Accepted, September 8, 2018 